\title{
Review \\ Imprinted Polymers as Synthetic Receptors in Sensors for Food Safety
}

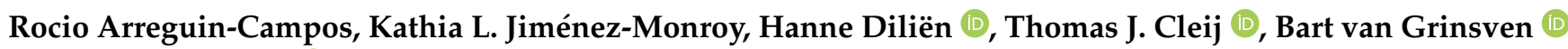 \\ and Kasper Eersels *(D)
}

check for updates

Citation: Arreguin-Campos, R.; Jiménez-Monroy, K.L.; Diliën, H.; Cleij, T.J.; van Grinsven, B.; Eersels, K. Imprinted Polymers as Synthetic Receptors in Sensors for Food Safety. Biosensors 2021, 11, 46. https:// doi.org/10.3390/bios11020046

Academic Editor: Cosimino Malitesta

Received: 22 January 2021

Accepted: 6 February 2021

Published: 11 February 2021

Publisher's Note: MDPI stays neutral with regard to jurisdictional claims in published maps and institutional affiliations.

Copyright: (c) 2021 by the authors. Licensee MDPI, Basel, Switzerland. This article is an open access article distributed under the terms and conditions of the Creative Commons Attribution (CC BY) license (https:// creativecommons.org/licenses/by/ $4.0 /)$.
Sensor Engineering Department, Faculty of Science and Engineering, Maastricht University, P.O. Box 616, 6200 MD Maastricht, The Netherlands; r.arreguincampos@maastrichtuniversity.nl (R.A.-C.); k.jimenezmonroy@maastrichtuniversity.nl (K.L.J.-M.); hanne.dilien@maastrichtuniversity.nl (H.D.); thomas.cleij@maastrichtuniversity.nl (T.J.C.); bart.vangrinsven@maastrichtuniversity.nl (B.v.G.)

* Correspondence: kasper.eersels@maastrichtuniversity.nl

\begin{abstract}
Foodborne illnesses represent high costs worldwide in terms of medical care and productivity. To ensure safety along the food chain, technologies that help to monitor and improve food preservation have emerged in a multidisciplinary context. These technologies focus on the detection and/or removal of either biological (e.g., bacteria, virus, etc.) or chemical (e.g., drugs and pesticides) safety hazards. Imprinted polymers are synthetic receptors able of recognizing both chemical and biological contaminants. While numerous reviews have focused on the use of these robust materials in extraction and separation applications, little bibliography summarizes the research that has been performed on their coupling to sensing platforms for food safety. The aim of this work is therefore to fill this gap and highlight the multidisciplinary aspects involved in the application of imprinting technology in the whole value chain ranging from IP preparation to integrated sensor systems for the specific recognition and quantification of chemical and microbiological contaminants in food samples.
\end{abstract}

Keywords: imprinted polymers; food safety; biomimetic sensor

\section{Introduction}

With the increasing globalization of food trade and supply, food safety is an issue able to trigger health emergencies with international impact, for example the Listeriosis outbreak in South Africa (2017-2018), Europe (2018) and Spain (2019) [1], which required a multinational collaboration. The World Health Organization estimates about 600 million cases of foodborne diseases (FBD) every year [2]. FBD can range from diarrhea to cancers and affects nearly 1 out of 10 people globally [3]. Apart from the impact on human well-being, economic costs related to FBD include productivity losses, treatment of the diseases, domestic market disruption and costumer product avoidance [4]. Therefore, strict controls and tools able to assess that all foods remain safe, wholesome and fit for human consumption are essential.

A hazard, in terms of food safety, is any agent that can cause an adverse health effect, and can be classified by its physical, chemical or biological nature [5]. The prevention and accurate identification of these agents in the food supply chain is fundamental for avoiding FBD. Food needs to go through a multistep process with a variable number of actors from production to consumption [6]. Such a dynamic system requires adequate technologies for the detection of chemical (e.g., pesticides or drug resides) and biological contaminants (bacteria, viruses and parasites). Analytical methods used for detecting chemical agents in food are gas and liquid chromatography, often in combination with mass spectrometry [7]. Biological detection, on the other hand, can be performed using traditional microbiological culturing, electrophoresis and polymerase chain reaction-based methods. These techniques can be costly and/or time-consuming, emphasizing the need for reliable, cost-effective and fast detection technologies [8]. Sensors, which possess these characteristics, are also 
suitable for detecting both chemical and biological agents and could be adapted to the requirements of each step of the food supply chain [9].

Sensing platforms can be described as two-component systems consisting of: (i) a recognition element, able to bind and provide a response when the targeted analyte is present; and (ii) a transducer, which converts the interactions derived from the binding of the recognition element with the target into analytical signals $[10,11]$. Sensors based on biological recognition elements (e.g., enzymes, nucleic acids, antibodies, cells, etc.) are the most researched not only in terms of food safety, but also for medical diagnostics and environmental monitoring [12]. Biological receptors, however, are fragile; require carefully regulated operational conditions such as $\mathrm{pH}$ values, ionic strength or temperature; and have a limited shelf life [13]. Biomimetic or synthetic receptors, as alternatives, are able to attain the affinity of biological receptors and overcome stability and durability issues [14-16].

Imprinted polymers (Ips) have attracted attention due to their simplicity in preparation and affinity attained as recognition element. The versatility of Ips enables detection of small molecules (Molecularly Imprinted Polymers, MIPs) [17-19] and whole cells (Surface Imprinted Polymers, SIPs) [20-22]. Furthermore, they can be coupled to different transducing elements such as microgravimetric [23-25], optical [26,27], thermal [28-30] and electrochemical [31-34] read-out platforms, among others.

FBD are certainly foreseen to rise in the upcoming years due to the increased complexity of food supply chains. Factors such as the globalization in food trade, changes of patterns in human consumption and climate change are only some of the underlying reasons more diseases related to harmful organisms and chemicals are expected [27,28]. Even though biomimetic sensors are suitable to detect these agents and have proven to possess several advantages over biosensors, their specific application in food safety has barely been reviewed $[35,36]$.

This work covers the types of imprinted polymers that have been developed for the detection of chemical and biological hazards in food, their preparation strategies, coupling to different readout platforms and application in real food samples.

\section{Imprinted Polymers}

As mentioned above, biosensors are receptor-transducer devices defined as "chemical sensors in which the recognition system utilizes a biological element" [37]. This system involves specific receptor-ligand interactions, where complementarity of geometry and chemical functionality (e.g., covalent interactions, hydrogen bonds, van der Waals forces, etc.) define selectivity [38]. Decades of efforts using natural recognition elements as inspiration have resulted in diverse strategies for preparing synthetic receptors that mimic the function of biological receptors [39-41]. Furthermore, with the first report of artificial antibodies [42], the interest in molecularly imprinted polymers (MIPs) increased [15,43,44]. Imprinted polymers are excellent candidates for bio(mimetic) sensing platforms due to their simplicity in preparation, attained affinity and stability compared to their natural counterparts $[15,17,38,44-48]$. Moreover, imprinted polymers are robust materials that can be coupled to a transducer surface to exhibit sensitive and reliable signals, which has enabled their application in clinical [18,19,49,50], environmental [51,52], agricultural and food diagnostics [53].

\subsection{Imprinted Polymers: Preparation Strategies According to the Template's Size}

\subsubsection{Molecularly Imprinted Polymers}

MIPs are functional materials with specific recognition sites that, in a general view, are synthesized via the polymerization of functional monomers in the presence of a molecular template. The general procedure for synthesizing a MIP is illustrated in Figure 1. Firstly, the monomer and template are dissolved in an appropriate solvent (porogen). Due to intermolecular interactions that can be of covalent, noncovalent, semi-covalent or coordinative nature, the template and monomers self-assemble, forming a complex $[15,17,54,55]$. 
Subsequently, the monomers are polymerized and the material is cross-linked. Upon the removal of the template molecule, defined three-dimensional micro- or nano-cavities will remain in the polymer, able to recognize the original template. The supramolecular events of interaction (e.g., covalent or non-covalent) and shape complementarity resemble the natural mechanism of natural receptors toward their targets $[55,56]$.

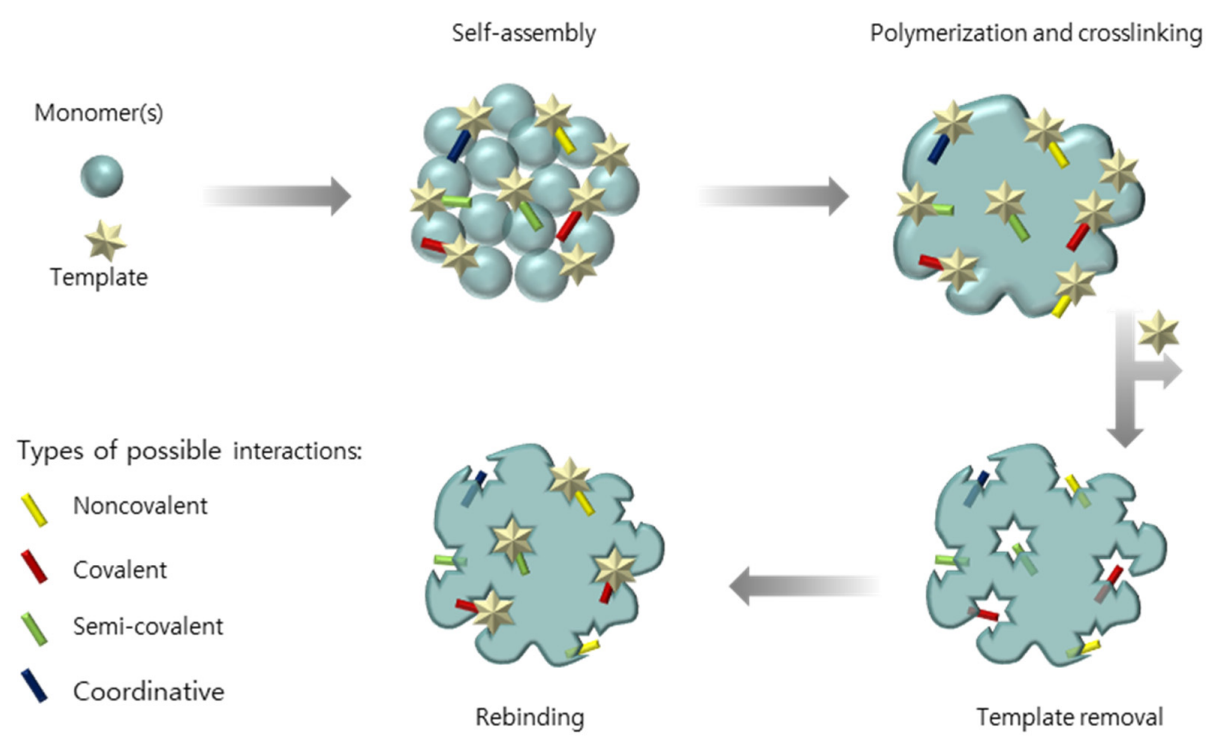

Figure 1. Synthetic steps to prepare MIPs.

Even though self-assembly is the general principle by which MIPs are prepared, several experimental strategies leading to materials with different physicochemical characteristics can be followed. These preparation methods are briefly described in this section.

Bulk imprinting method is the oldest and most commonly reported strategy due to its simplicity. It typically employs free radical polymerization (FRP), which is carried out in solution with the aid of a thermal or UV initiator $[57,58]$. The use of FRP has the advantages of mild reaction conditions as well as suitability for various monomers (vinylcontaining molecules) and templates [42]. The solid monolith obtained after polymerization is subsequently ground and sieved to obtain MIP particles. Even though "bulk" preparation of MIPs is versatile and easily scalable, some disadvantages such as polymer loss and low binding kinetics as result of crushing the imprinted monolith have been identified $[59,60]$.

Precipitation polymerization is a strategy that allows the synthesis of polymeric microor nano-spheres with a controlled morphology. As in bulk preparation of MIPs, FRP of the monomers is most commonly employed, with the experimental variant of using an excess of solvent in which the precursors (template and monomers) are soluble, but the forming polymer is not. As the reaction proceeds, polymer nuclei form, and, by growing, they segregate from the solution to form micro- or sub-micrometer-sized beads [61,62]. In contrast to the preparation of MIPs in the bulk, the polymer obtained does not require additional grinding steps.

Emulsion polymerization enables the formation of homogenous imprinted polymer particles. Similar to the two previously mentioned strategies, emulsion usually employs FRP. The reaction mixture, however, consists of a biphasic (typically aqueous and organic) system and a surfactant, which enables the formation of an emulsion and, thus, the growth of the polymer in the dispersed phase in a core-shell manner $[63,64]$.

Solid-phase synthesis consists of the immobilization of the initiator or the template onto a solid support in order to carry out the polymerization directly from it. When immobilizing the template, it is possible to remove low affinity imprinted polymer as well as unreacted monomer after the synthesis [65]. On the other hand, when immobilizing the initiator, diverse controlled free radical polymerization techniques such as reversible addition fragmentation chain-transfer polymerization (RAFT) and atom transfer radical 
polymerization (ATRP) can be used with the advantages of obtaining more homogeneous polymer networks and thus higher target affinities in comparison to the traditional free radical polymerization [66-68].

Electro-polymerization consists of the oxidation of conjugated monomers and the deposition of a conductive polymer film onto a substrate. The synthesis system for these layers consists of a solution containing the monomer(s), the template, an electrolyte and three electrodes (working, reference and counter) [69]. Typically, the working electrode serves as deposition substrate for the material, and a wide variety of electrochemical techniques can be employed for the electrosynthesis (galvanostatic, potentiostatic and voltammetric). By adjusting the experimental conditions for electro-polymerization, it is possible to adjust the thickness, topology and morphology of the imprinted films [70-72].

Numerous reviews deal with the aspects of MIP synthesis and processing [17,61,73]. Although these biomimetic receptors have successfully proven their applicability for detecting low molecular weight compounds, larger molecules such as enzymes, proteins and cells turned out to be more challenging. The steps of template removal and rebinding are especially difficult since macromolecules cannot penetrate the small porous network in a straightforward manner $[45,74-76]$. These issues have been overcome by using different imprinting strategies, creating surface imprinted polymers (SIPs) [10,22,75,77].

\subsubsection{Surface Imprinted Polymers}

Synthesis of SIPs involve the fundamentals of MIP preparation; however, in SIPs the recognition sites are located at or near the surface of the forming polymeric material, facilitating the imprinting of macromolecular targets such as proteins, microorganisms or whole cells. Compared to traditional MIPs, SIPs exhibit higher binding capacity, faster mass transfer and binding kinetics [76]. Depending on how the polymer cavities are formed, SIPs can be classified as follows (Figure 2) [10]:

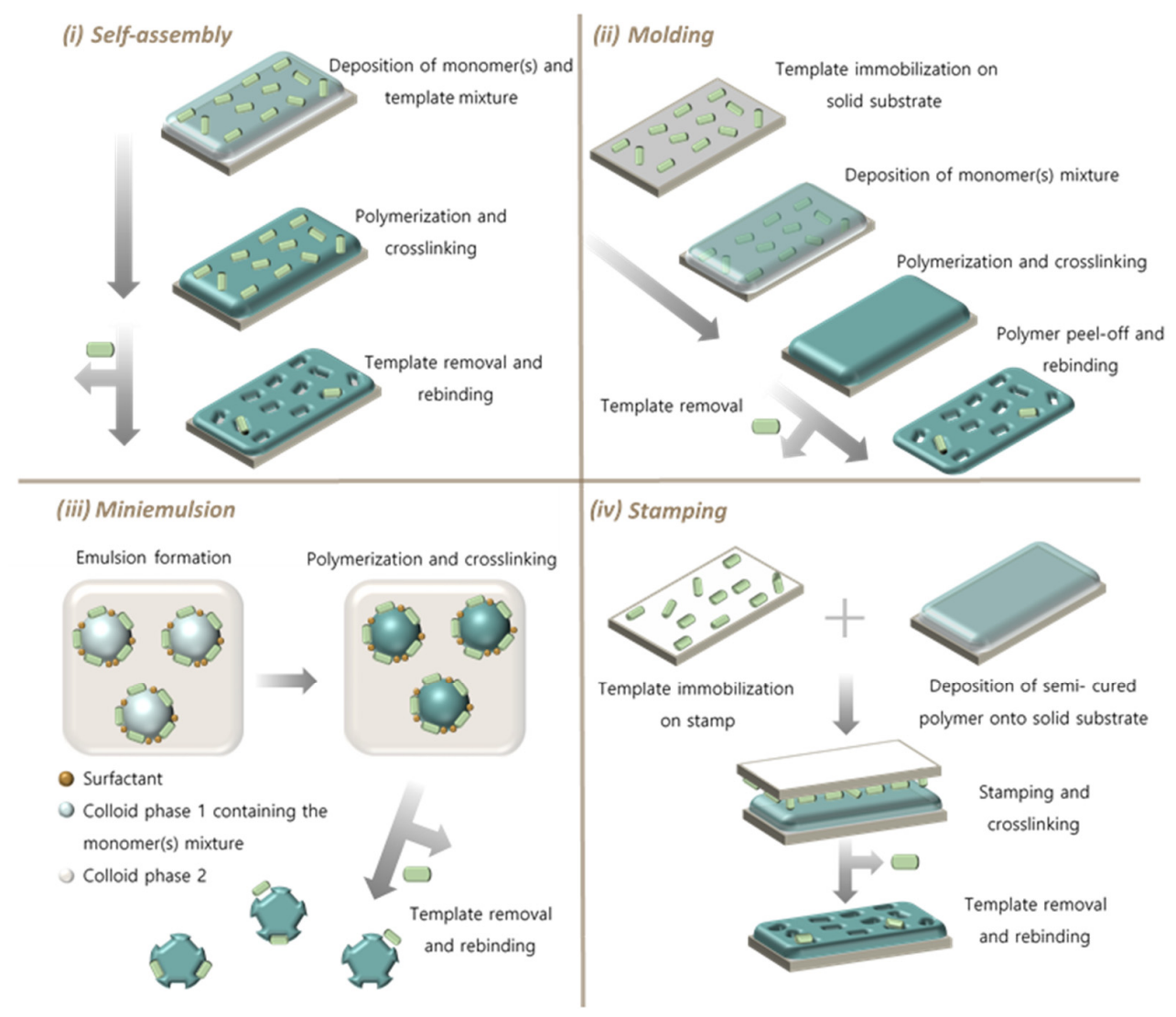

Figure 2. Synthetic steps to prepare SIPs: (i) self-assembly method; (ii) molding technique; (iii) miniemulsion polymerization; and (iv) stamping technique. 
Self-assembly method: A polymerization mixture containing the functional monomers and template is prepared. The reaction is performed in a similar way as in traditional MIP synthesis, with the difference that, upon template removal, the only functional cavities formed are the ones situated on the surface of the material [78,79]. A variant for this method is the directed self-assembly of the monomer around the template driven by an applied physical force (electro-polymerization), which was introduced before for MIP preparation [80].

Molding technique: The template is immobilized on a solid substrate and the reaction mixture with monomers is added on top of it. The polymerization and crosslinking reactions are carried out, and, upon peeling off the polymer and removing the template, the cavities on the material's surface are obtained [81,82].

Stamping or micro-contact printing technique: The functional monomers are semipolymerized, and this material is applied onto a solid substrate. Separately, a monolayer of template particles is fixed on the surface of a stamp, which is subsequently pressed onto the semi-cured material. The cross-linking is completed in the presence of the stamp, such that, when this stamp is removed, the template has been transferred to the material, and, by taking it out, cavities are formed $[50,83,84]$.

Mini-emulsion polymerization: The polymerization is performed in a colloidal system with the aid of a surfactant. Derived from this, the polymer grows in the physical form of small spheres, and, because the template particles arrange in the interphase of the colloid, the cavities are formed on the surface of the beads $[85,86]$.

These methods have allowed MIPs/SIPs to be used for different purposes such as sample preparation, solid phase extraction and reaction catalysis, among others $[87,88]$. Moreover, these applications have been researched for application in the agricultural and food sectors due to the constant need of analytical techniques that aid to ensure food quality and safety, meeting the consumer's requirements and avoiding FBD [89]. Although sensing based on biomimetic receptors has the potential of being a highly selective and useful tool in the detection of food safety hazards, reviews of IP in food science have focused mostly on extraction and separation applications [90-93]. Our aim is to fill this gap and highlight the multidisciplinary aspects involved in the application of imprinting technology in the whole value chain ranging from IP preparation to integrated sensor systems for the specific recognition and quantification of chemical and microbiological contaminants in food samples.

\section{Chemical Food Hazards}

A wide variety of chemical compounds can be the cause of FBDs. These substances can be naturally present in food, such as allergens, or can result from the production and processing steps. Agricultural chemicals (pesticides, fertilizers and veterinary drugs) are the most common chemical hazards from food production. Moreover, some compounds migrating from packaging, food additives and contaminants produced during storage also have the potential of causing health damage [94]. Due to the broad variety of food chemical hazards, this work focuses mainly on the imprinting strategies to recognize pesticides and drugs (agricultural chemicals) in food samples (Tables 1 and 2), while an additional section briefly summarizes other chemical food contaminant categories (Table 3).

Agrochemicals are used worldwide. Pesticides, for example, have the purpose of preventing and destroying any unwanted species of plant or animal (e.g., weeds and insects) in foods in order to regulate their growth and prevent their deterioration [95]. Another class of chemicals frequently used in agriculture are pharmacologically active compounds, or drugs, which aim to ensure the health of animals involved in food production. Despite the beneficial role that pesticides and drugs have, inadequate use can cause short- or long-term adverse health effects. Pesticides (e.g., carbamates, organophosphates and pyrethroids) can have carcinogenic, cytotoxic and mutagenic effects [96-98]. On the other hand, administering drugs (antibiotics) to animals intended for human consumption can have negative effects such as the emergence, spreading and persistence of antimicrobial- 
resistant bacteria among humans [99]. Furthermore, the illicit use of these compounds in animals can turn into severe poisoning outbreaks, such as the ones originated in France (1990) and Spain (1992) due to the consumption of clenbuterol [100].

The detection of chemical residues in food is essential in the prevention of FBDs, and it often requires the accurate detection of trace concentration. Pesticides are usually quantified using gas chromatography-mass spectroscopy (GC-MS), while drugs are detected with liquid chromatography due to their more polar chemical nature [101]. However, analysis of agricultural chemistry in food safety remains a challenge due to the broad diversity in chemical compounds and their presence at low concentrations in complex matrices [102]. Due to their specificity, IPs have been developed to recognize pesticides and drugs in real food samples. Research efforts studying these receptors are aimed at the selection of the target chemical contaminant, selection of functional materials and choosing an imprinting strategy. The specific synthesis protocol of IPs has a huge influence on their selectivity, a fundamental aspect of technologies for food hazard detection [103].

\subsection{Imprinting Technology for the Recognition of Chemical Food Hazards}

Most chemical food hazards are low-molecular-weight compounds, which is the main reason MIPs have been extensively used for their detection. However, some surface imprinting techniques have also been adapted to create receptors for the recognition of these small analytes. This section aims to summarize how these diverse preparation strategies for IPs have been applied to the recognition of these analytes in real food samples.

\subsubsection{Pesticides}

Abdel-Ghany et al. illustrated in their work how you could exploit traditional bulk preparation for the imprinting of dinotefuran insecticide using acrylamide and methacrylic acid as monomers with ethylene glycol dimethacrylate as cross-linker. Different compositions of these building blocks were tested. The obtained MIP powder was integrated into membranes with the aid of a plasticizer and then embodied into the sensing device, which was evaluated for the detection of the insecticide in cucumber and soil samples. Before the recognition experiments, samples were pre-treated by chopping and blending them, followed by sonication and centrifugation, steps that were performed with the aim of ensuring the extraction of the target. The recognition ability of the polymer was assessed by recovering the analyte from the real samples, obtaining average values in the range of $7.9-106.4 \%$. Furthermore, the integration of the IP into the sensing device allowed the determination of dinotefuran with a limit of detection (LoD) of $0.35 \mu \mathrm{g} \mathrm{L}^{-1}$. Apart from these experiments, selectivity experiments against some related substances were performed [104].

Motaharian et al. presented a similar technique for recognition of diazinon. They used imprinted polymer beads, which were prepared by carrying out polymerization of the monomers (methacrylic acid and ethylene glycol dimethacrylate) in a biphasic system of chloroform and silicon oil. To incorporate the obtained spheres $(<100 \mathrm{~nm})$ into the sensor, the beads were mixed with graphite and paraffin oil as binder to prepare a carbon paste electrode. The synthetic receptor was employed to recognize the analyte in blended apple solutions, from which recovery values in the range of $92.5-100.8 \%$ were obtained. When combining the spherical receptors to the sensor, detection of the analyte was achieved with an LoD of $7.9 \times 10^{-10} \mathrm{~mol} \mathrm{~L}^{-1}$ [105].

$\mathrm{Li}$ et al. demonstrated the use of electro-polymerized MIPs for the electrochemical detection of the pyrethroid pesticide cypermethrin. Dopamine and resorcinol were investigated in order to take advantage of the synergic affinity of the two different monomers. The imprinted polymer films were deposited by cyclic voltammetry on a glassy carbon electrode using phosphate buffer as electrolyte. The sensor obtained was a hybrid material composed of the IP and a support layer of doped zinc oxide, which was prepared on the surface of the electrode previously to the electrodeposition. The recognition element was then tested on mackerel and crayfish, samples from which the abdominal meat was 
homogenized, centrifuged and extracted in ethanol. The accuracy of the prepared sensor in these complex samples was verified with the observed recoveries from $96.2 \%$ to $100.4 \%$. As for the application of the polymer film in the sensing platform, the LoD obtained was $6.7 \times 10^{-14} \mathrm{M}$ [106]. Over the years, a wide variety of similar MIP-based sensors have been developed for the detection of pesticides, which are summarized in Table 1.

Table 1. Summary of recent publications for the recognition of pesticides using IPs in food samples.

\begin{tabular}{|c|c|c|c|c|c|c|}
\hline Analyte (s) & $\begin{array}{l}\text { Template/ } \\
\text { Monomer(s)/ } \\
\text { Crosslinker }\end{array}$ & IP Preparation & Food Sample & LoD & $\begin{array}{l}\text { Readout } \\
\text { Technique }\end{array}$ & Ref. \\
\hline Malathion & $\begin{array}{c}\text { Malathion/ } \\
\text { Acrylamide/ } \\
\text { Bisacrylamide }\end{array}$ & Thermal: Bulk & Olive fruits, oils & $0.06 \mathrm{pg} / \mathrm{mL}$ & Electrochemical & [107] \\
\hline Cyromazine & $\begin{array}{c}\text { Cyromazine/ } \\
\text { MAA/EGDMA }\end{array}$ & $\begin{array}{c}\text { Thermal: } \\
\text { Precipitation }\end{array}$ & $\begin{array}{c}\text { Agricultural } \\
\text { waste water, soil }\end{array}$ & $2.6 \times 10^{-6} \mathrm{M}$ & Electrochemical & [108] \\
\hline Dinotefuran & $\begin{array}{c}\text { Dinotefuran/ } \\
\text { MAA/EGDMA }\end{array}$ & Thermal: Bulk & Cucumber, soil & $0.35 \mu \mathrm{g} / \mathrm{L}$ & Electrochemical & [104] \\
\hline Diazinon & $\begin{array}{c}\text { Diazinon/ } \\
\text { MAA/EGDMA }\end{array}$ & $\begin{array}{l}\text { Thermal: } \\
\text { Suspension }\end{array}$ & Apple, well water & $7.9 \times 10^{-10} \mathrm{~mol} / \mathrm{L}$ & Electrochemical & [105] \\
\hline Dicloran & $\begin{array}{c}\text { Dicloran/ } \\
\text { MAA/EGDMA }\end{array}$ & Thermal: Bulk & Water & $4.8 \times 10^{-10} \mathrm{~mol} / \mathrm{L}$ & Electrochemical & [109] \\
\hline Lindane & $\begin{array}{c}\text { Lindane/ } \\
\text { MAA/EGDMA }\end{array}$ & $\begin{array}{l}\text { Thermal: From } \\
\text { MWCN surface }\end{array}$ & $\begin{array}{l}\text { Orange, grape, } \\
\text { tomato, cabbage }\end{array}$ & $1.0 \times 10^{-10} \mathrm{M}$ & Electrochemical & [110] \\
\hline Carbaryl & $\begin{array}{c}\text { Carbaryl/ } \\
\text { MAA/EGDMA }\end{array}$ & $\begin{array}{l}\text { Thermal: From } \\
\text { QD surface }\end{array}$ & $\begin{array}{l}\text { Chinese cabbage, } \\
\text { rice }\end{array}$ & $1.47 \times 10^{-7} \mathrm{~mol} / \mathrm{L}$ & Optical & [111] \\
\hline Metolcarb & $\begin{array}{c}\text { Metolcarb/ } \\
\text { MAA/EGDMA }\end{array}$ & Thermal: Bulk & $\begin{array}{l}\text { Apple juice, pear, } \\
\text { cabbage }\end{array}$ & $2.309 \mu \mathrm{g} / \mathrm{L}$ & $\begin{array}{l}\text { Acoustic } \\
\text { wave }\end{array}$ & [112] \\
\hline Cyanazine & $\begin{array}{l}\text { Cyanazine/ } \\
\text { Acrylamide/ } \\
\text { EGDMA }\end{array}$ & Thermal: Bulk & $\begin{array}{l}\text { Onion, tomato, } \\
\text { lettuce }\end{array}$ & $3.2 \mathrm{nM}$ & Electrochemical & [113] \\
\hline Phosalone & $\begin{array}{c}\text { Phosalone/ } \\
\text { APTES/TEOS }\end{array}$ & $\begin{array}{l}\text { Thermal: } \\
\text { Sol-gel }\end{array}$ & $\begin{array}{l}\text { Cucumber, } \\
\text { orange, wheat, } \\
\text { water, soil }\end{array}$ & $0.078 \mathrm{nM}$ & Electrochemical & [114] \\
\hline Trichlorfon & $\begin{array}{c}\text { Trichlorfon/ } \\
\text { Vinylidene difluoride }\end{array}$ & $\begin{array}{l}\text { Pre-synthesized } \\
\text { polymer }\end{array}$ & Lettuce & $4.63 \mathrm{ppb}$ & $\begin{array}{l}\text { Acoustic } \\
\text { wave }\end{array}$ & [115] \\
\hline 2,4-dichlorophenol & $\begin{array}{l}\text { 2,4-dichlorophenol/ } \\
\text { 3,4-EDOT }\end{array}$ & $\begin{array}{l}\text { Electrochemical: } \\
\text { Deposition }\end{array}$ & Water & $0.07 \mathrm{nM}$ & Electrochemical & [116] \\
\hline Carbendazim & $\begin{array}{c}\text { Carbendazim/ } \\
\text { o-phenylenediamine }\end{array}$ & $\begin{array}{l}\text { Electrochemical: } \\
\text { Deposition }\end{array}$ & $\begin{array}{l}\text { Diverse fruits and } \\
\text { vegetables }\end{array}$ & $6.7 \times 10^{-13} \mathrm{M}$ & Electrochemical & [117] \\
\hline Cypermethrin & $\begin{array}{c}\text { Cypermethrin/ } \\
\text { Dopamine, resorcinol }\end{array}$ & $\begin{array}{l}\text { Electrochemical: } \\
\text { Deposition }\end{array}$ & $\begin{array}{l}\text { Soil, mackerel, } \\
\text { crayfish, water }\end{array}$ & $6.7 \times 10^{-14} \mathrm{M}$ & Electrochemical & [106] \\
\hline Methyl-parathion & $\begin{array}{l}\text { Methyl-parathion/ } \\
\text { Resorcinol, quercetin }\end{array}$ & $\begin{array}{l}\text { Electrochemical: } \\
\text { Deposition }\end{array}$ & Fruit surfaces & $3.4 \times 10^{-10} \mathrm{~mol} / \mathrm{L}$ & Electrochemical & [118] \\
\hline
\end{tabular}

MAA, Methacrylic acid; EGDMA, ethylene glycol dimethacrylate; APTES, (3-aminopropyl) triethoxysilane; TEOS, Tetraethyl orthosilicate; EDOT, Ethylenedioxythiophene; TRIM, Trimethylopropane trimethacrylate; MAGA, Methacryloylamidoglutamic acid; HEMA, Hydroxyethyl methacrylate; APBA, 3-aminophenylboronic acid, QD, Quantum dots; MWCN, Multi-walled carbon nanotubes; MNP, Magnetic nanoparticles.

As pesticides are low-molecular weight compounds, the literature is focused on the creation of MIPs rather than SIPs. Bulk polymerization has been demonstrated to be suseful and has even led to the development of sensitive platforms that can compete in LoD with sensors using MIPs created via more advanced routes. This offers the benefit of being able to make proof-of-concept platforms in a fast manner. Suspension and precipitation polymerization platforms are in general a bit more sensitive but are also more suitable for upscaling due to their increased homogeneity. In terms of scalability, electro-polymerized MIPs offer a very interesting approach in constructing MIP-based sensors but, as evidenced by the results in Table 1, are often only combined with electrochemical detection platforms and require a long process of fine-tuning. 


\subsubsection{Drugs}

In addition to pesticides and insecticides, a wide range of MIP sensors that focus on the detection of drugs in food samples has been developed in the past few decades. In 2013, Chen et al. made use of core-shell imprinted particles that were prepared for the detection of metronidazole antibiotic. The IP was synthesized using (3-aminopropyl)triethoxysilane and tetraethyl orthosilicate as monomers. The polymerization reaction was carried on the surface of silica coated $\mathrm{Fe}_{3} \mathrm{O}_{4}$ nanoparticles, which were employed as solid support due to their chemical stability and magnetic properties. The obtained IP particles were drop casted onto a magnetic glassy carbon electrode. The receptor was tested for the recognition of the antibiotic in milk and honey samples, which were prepared by homogenization, centrifugation and filtration before the rebinding experiments. The performance of the synthetic receptor in these samples was assessed with the recovery percentages, which were $93.5-102.2 \%$. The magnetic particles were further tested in a sensing platform, which attained a LoD of $1.6 \times 10^{-8} \mathrm{M}$ [119].

Wei et al. demonstrated the use of electro-polymerized MIPs for the detection of the antibacterial agent sulfadimine in 2019. Electrodeposition of the conjugated monomer polypyrrole was performed on the surface of $\mathrm{NiCo}_{2} \mathrm{O}_{4}$ nanoneedle arrays in order to construct a highly selective MIP-sensor. The nanoneedles were selected for their use with IP due to their high specific surface area, which enables them to enhance the performance of detection. These arrays were synthesized and decorated onto a graphene electrode, which was subsequently used as working electrode in the electropolymerization via cyclic voltammetry using tetrabutylammonium perchlorate as supporting electrolyte. The fabricated electrode was employed for the detection of this drug in milk. The food samples were pre-treated to remove protein and dissolve organic substances with acetonitrile and trichloroacetic acid. Recovery values from these samples were of $92.3-102.2 \%$. Additionally, the application of the nanoneedle array/pyrrole in a sensing device led to a LoD of $0.169 \mathrm{ng} \mathrm{mL}^{-1}$ [120]. Other examples of MIP-based drug detection in food samples are summarized in Table 2.

Looking at the summary in Table 2, the same conclusions that apply for pesticides can also be drawn for MIP-based drug detection in food products. Bulk imprinted MIPs offer a fast track solution to constructing a first prototype sensor that is surprisingly sensitive and can compete with more advanced systems incorporating for instance MWCNs into the synthetic receptor layer. This does boost the sensitivity of an electrochemical sensor but not by multiple orders of magnitude. Electro-deposition again proves to be an excellent match for electrochemical detection of drug molecules offering fast synthesis, immediate deposition and therefore scalability. 
Table 2. Summary of recent publications for the recognition of drugs using IPs in food samples.

\begin{tabular}{|c|c|c|c|c|c|c|}
\hline Analyte (s) & $\begin{array}{l}\text { Template/ } \\
\text { Monomer(s)/ } \\
\text { Crosslinker }\end{array}$ & IP Preparation & Food Sample & LoD & $\begin{array}{l}\text { Readout } \\
\text { Technique }\end{array}$ & Ref. \\
\hline $\begin{array}{l}\text { Amantadine and } \\
\text { rimantadine }\end{array}$ & $\begin{array}{l}\text { Amantadine/ } \\
\text { MAA/EGDMA }\end{array}$ & Thermal: Bulk & Chicken, pork & $1.0 \mathrm{pg} / \mathrm{mL}$ & Optical & [121] \\
\hline Chloramphenicol & $\begin{array}{l}\text { Chloramphenicol/ } \\
\text { MAA/EGDMA }\end{array}$ & Thermal: Bulk & Milk & $2.0 \times 10^{-9} \mathrm{M}$ & Electrochemical & [122] \\
\hline Chloramphenicol & $\begin{array}{l}\text { Chloramphenicol/ } \\
\text { MAA/EGDMA }\end{array}$ & Thermal: Bulk & Milk & $10 \mu \mathrm{M}$ & Electrochemical & [123] \\
\hline Clenbuterol & $\begin{array}{c}\text { Clenbuterol/ } \\
\text { MAA/EGDMA }\end{array}$ & Thermal: Bulk & Bovine liver & $0.2 \mathrm{nM}$ & Electrochemical & [124] \\
\hline Sulfonamides & $\begin{array}{c}\text { Sulfabenz/ } \\
\text { MAA/EGDMA }\end{array}$ & Thermal: Bulk & Chicken, pork & $1-12 \mathrm{pg} / \mathrm{mL}$ & Optical & {$[125]$} \\
\hline Kanamycin & $\begin{array}{c}\text { Kanamycin/ } \\
\text { MAA/EGDMA }\end{array}$ & $\begin{array}{l}\text { Thermal: From } \\
\text { MWCN surface }\end{array}$ & $\begin{array}{l}\text { Chicken, pig, } \\
\text { milk }\end{array}$ & $2.3 \times 10^{-11} \mathrm{~mol} / \mathrm{L}$ & Electrochemical & [126] \\
\hline Sulfaguanidine & $\begin{array}{l}\text { Sulfaguanidine/ } \\
\text { MAA/EGDMA }\end{array}$ & Thermal: Bulk & Fish & $2.8 \times 10^{-10} \mathrm{~mol} / \mathrm{L}$ & Optical & [127] \\
\hline Quinolones & $\begin{array}{l}\text { Enrofloxacin/ } \\
\text { MAA/EGDMA }\end{array}$ & Photo: Bulk & Fish & $4.06 \times 10^{-7} \mu \mathrm{mol} / \mathrm{L}$ & Optical & [128] \\
\hline Benzimidazoles & $\begin{array}{l}\text { Mebendazole, } \\
\text { fuberidazole/ } \\
\text { MAA/EGDMA }\end{array}$ & Thermal: Bulk & Mutton, beef & $21 \mathrm{pg} / \mathrm{mL}$ & Optical & [129] \\
\hline Chloramphenicol & $\begin{array}{l}\text { Chloramphenicol/ } \\
\text { MAA/TRIM } \\
\text { Oxytocin/ }\end{array}$ & Thermal: Bulk & Prawns & $7.8 \times 10^{-8} \mu \mathrm{M} / \mathrm{mL}$ & Acoustic wave & [130] \\
\hline Oxytocin & $\begin{array}{c}\text { MAGA,2-HEMA/ } \\
\text { EGDMA }\end{array}$ & Thermal: Bulk & Milk & $0.003 \mathrm{ng} / \mathrm{mL}$ & Optical & [131] \\
\hline Estradiol & Estradiol/Aniline & Thermal: Bulk & Milk powder & $2.76 \mathrm{nmol} / \mathrm{L}$ & Electrochemical & [132] \\
\hline Diethylstilbestrol & $\begin{array}{c}\text { Diethylstilbestrol/ } \\
\text { APBA }\end{array}$ & $\begin{array}{l}\text { Thermal: From } \\
\text { MNP surface }\end{array}$ & Milk & $2.5 \times 10^{-10} \mathrm{~mol} / \mathrm{L}$ & Electrochemical & [133] \\
\hline Metronidazole & $\begin{array}{l}\text { Metronidazole/ } \\
\text { APTES/TEOS }\end{array}$ & Thermal: Bulk & Milk, honey & $1.6 \times 10^{-8} \mathrm{M}$ & Electrochemical & [119] \\
\hline Vitamin $\mathrm{K}_{3}$ & $\begin{array}{l}\text { Vitamin } \mathrm{K}_{3} / \\
\text { 3,4-EDOT }\end{array}$ & $\begin{array}{l}\text { Electrochemical: } \\
\text { Deposition }\end{array}$ & $\begin{array}{l}\text { Poultry drug } \\
\text { powder }\end{array}$ & $3.1 \times 10^{-4} \mu \mathrm{M}$ & Electrochemical & [134] \\
\hline Tobramycin & Tobramycin/Pyrrole & $\begin{array}{l}\text { Electrochemical: } \\
\text { Deposition }\end{array}$ & Egg, milk & $1.4 \times 10^{-10} \mathrm{M}$ & Electrochemical & [135] \\
\hline Oxfendazole & $\begin{array}{l}\text { Oxfendazole/ } \\
\text { Pyrrole }\end{array}$ & $\begin{array}{l}\text { Electrochemical: } \\
\text { Deposition }\end{array}$ & Milk & $10 \mu \mathrm{g} / \mathrm{Kg}$ & Electrochemical & [136] \\
\hline Sulfadimidine & $\begin{array}{l}\text { Sulfadimidine/ } \\
\text { Pyrrole }\end{array}$ & $\begin{array}{l}\text { Electrochemical: } \\
\text { Deposition }\end{array}$ & Milk & $0.169 \mathrm{ng} / \mathrm{mL}$ & Electrochemical & [120] \\
\hline Streptomycin & $\begin{array}{c}\text { Streptomycin/ } \\
\text { o-phenylenediamine }\end{array}$ & $\begin{array}{l}\text { Thermal: } \\
\text { Suspension }\end{array}$ & Milk, honey & $10 \mathrm{pg} / \mathrm{mL}$ & Electrochemical & [137] \\
\hline
\end{tabular}

MAA, Methacrylic acid; EGDMA, ethylene glycol dimethacrylate; APTES, (3-aminopropyl) triethoxysilane; TEOS, Tetraethyl orthosilicate; EDOT, Ethylenedioxythiophene; TRIM, Trimethylopropane trimethacrylate; MAGA, Methacryloylamidoglutamic acid; HEMA, Hydroxyethyl methacrylate; APBA, 3-aminophenylboronic acid; MWCN, Multi-walled carbon nanotubes; MNP, Magnetic nanoparticles.

\subsubsection{Other Chemical Contaminants}

In addition to pesticides, insecticides and drugs, other chemical agents such as allergens can also pose a health risk (Table 3). In 2018, Ashley and coworkers demonstrated the use of imprinted nanoparticles for the detection of casein, a naturally occurring allergen in dairy products. Casein molecules were immobilized on glass beads, and solid-phase polymerization was used for the preparation of the imprinted receptors on these solid substrates. The monomers selected for the receptor were $\mathrm{N}$-isopropylacrylamide, $\mathrm{N}$-tertbutylacrylamide, acrylamide, $\mathrm{N}$-(3-aminopropyl)-methacrylamide and $\mathrm{N}, \mathrm{N}^{\prime}$-methylenebis (acrylamide), and the obtained particles exhibited physical dimensions from 235 to $457 \mathrm{~nm}$. The nanoparticles were tested on washed samples from cleaning in place systems used in food processing equipment, from which recoveries ranged $87-120 \%$. When employing 
the recognition ability of the nano-MIPs in a sensing device, the authors reported a limit of detection of $0.127 \mathrm{ppm}$. Remarkably, this LoD is superior to the sensitivity typically encountered in commercial ELISA kits [138].

Table 3. Summary of recent publications for the recognition of other chemical contaminants using IPs in food samples.

\begin{tabular}{|c|c|c|c|c|c|c|c|}
\hline Category & Analyte (s) & $\begin{array}{l}\text { Template/ } \\
\text { Monomer(s)/ } \\
\text { Crosslinker }\end{array}$ & IP Preparation & Food Sample & LoD & $\begin{array}{l}\text { Readout } \\
\text { Technique }\end{array}$ & Ref. \\
\hline $\begin{array}{l}\text { Naturally } \\
\text { occurring }\end{array}$ & $\alpha$-Casein & $\begin{array}{c}\alpha \text {-Casein/ } \\
\text { NIPAm, TBA, } \\
\text { AA, APM/BIS }\end{array}$ & $\begin{array}{c}\text { Thermal: From } \\
\text { glass beads }\end{array}$ & $\begin{array}{l}\text { CIP from dairy } \\
\text { ice cream }\end{array}$ & $0.127 \mathrm{ppm}$ & Optical & [138] \\
\hline Additives & Sudan dyes & $\begin{array}{l}\text { PN/MAA/ } \\
\text { EGDMA }\end{array}$ & Photo: Solution & Egg yolk & $1 \mathrm{pg} / \mathrm{mL}$ & Optical & [139] \\
\hline Additives & Sudan I & $\begin{array}{c}\text { Sudan I/ } \\
\text { 2-vinylpyridine/ } \\
\text { EGDMA }\end{array}$ & $\begin{array}{c}\text { Thermal: From } \\
\text { attapulguite } \\
\text { NC }\end{array}$ & $\begin{array}{l}\text { Tomato sauce, } \\
\text { sausage, water }\end{array}$ & $0.01 \mathrm{ng} / \mathrm{mL}$ & Optical & [140] \\
\hline $\begin{array}{l}\text { Naturally } \\
\text { occurring }\end{array}$ & Histamine & $\begin{array}{c}\text { Histamine/ } \\
\text { MAA/EGDMA }\end{array}$ & $\begin{array}{l}\text { Thermal: from } \\
\text { SPR chip }\end{array}$ & Carp & $25 \mu \mathrm{g} / \mathrm{L}$ & Optical & [141] \\
\hline $\begin{array}{l}\text { Naturally } \\
\text { occurring }\end{array}$ & Histamine & $\begin{array}{l}\text { Histamine/ } \\
\text { MPTES/TEOS }\end{array}$ & Sol-gel & Fish & $7.49 \times 10^{-4} \mathrm{mg} / \mathrm{kg}$ & $\begin{array}{c}\text { Acoustic } \\
\text { wave }\end{array}$ & [142] \\
\hline $\begin{array}{l}\text { Production, } \\
\text { packaging }\end{array}$ & Bisphenol A & $\begin{array}{l}\text { Bisphenol A/ } \\
\text { TEOS/APTES }\end{array}$ & Sol-gel & Water, milk & $1.46 \times 10^{-11} \mathrm{M}$ & Optical & [143] \\
\hline Production & Acrylamide & $\begin{array}{l}\text { Bisphenol A/ } \\
\text { APTES/TEOS }\end{array}$ & Sol-gel & Potato chips & $0.028 \mu \mathrm{g} / \mathrm{mL}$ & Electrochemical & [144] \\
\hline Production & Acrylamide & $\begin{array}{l}\text { Propionamide/ } \\
\text { HEA/EGDMA }\end{array}$ & $\begin{array}{l}\text { Thermal: From } \\
\text { GO electrode }\end{array}$ & Potato chips & $0.01 \mu \mathrm{g} / \mathrm{mL}$ & Optical & [145] \\
\hline Production & Melamine & $\begin{array}{c}\text { Melamine/ } \\
\text { MAA/EGDMA }\end{array}$ & $\begin{array}{l}\text { Photo: From } \\
\text { Au electrode }\end{array}$ & Milk & $3.1 \times 10^{-10} \mathrm{~mol} / \mathrm{L}$ & Electrochemical & [146] \\
\hline Production & Melamine & $\begin{array}{l}\text { Melamine/ } \\
\text { para-ABA }\end{array}$ & $\begin{array}{l}\text { Electrochemical: } \\
\text { Deposition }\end{array}$ & Milk & $0.36 \mu \mathrm{M}$ & Electrochemical & [147] \\
\hline Production & Melamine & Melamine/Pyrrole & $\begin{array}{l}\text { Electrochemical: } \\
\text { Deposition }\end{array}$ & Milk & $0.83 \mathrm{nM}$ & Electrochemical & [148] \\
\hline
\end{tabular}

CIP, Clean in place; NIPAm, N-isopropylacrylamide; TBA, N-tert-butylacrylamide; AA, Acrylic acid; APM, N-(3-aminopropyl)methacrylamide; BIS, N,N'-methylenebis (acrylamide); MAA, Methacrylic acid; EGDMA, ethylene glycol dimethacrylate; 3-MCPD, 3-chloro-1,2-propanediol; ABA, Aminobenzoic acid; APTES, (3-aminopropyl) triethoxysilane; TEOS, Tetraethyl orthosilicate; HEA, Hydroxy ethyl acrylate; PN, 1-(2-pyridinylazo)-2-naphthol;MPTES, 3-mercaptopropyltriethoxysilane; NC, Nanofibrillar clay; SPR, Surface plasmon resonance; GO, Graphite oxide.

MIP-based sensors for other chemical contaminants such as endocrine disruptors, toxins or chemicals typically employ more advanced imprinting technologies. This might be explained by the fact that bulk imprinting has already been done on these types of molecules in the more distant past, demonstrating the concept but also the limitations. The sensors in Table 3 offer a lot of benefits in term of mass-scale production as both electro-deposition and direct grafting onto gold or graphene electrodes allow for upscaling of production, which might be the biggest challenge when commercializing imprinting technology. Direct grafting onto electrodes offers the benefit of extending the potential transduction mechanisms used from electrochemical to optical or gravimetric techniques.

\section{Biological Food Hazards}

Diarrheal and gastroenteritis diseases account for the majority of the yearly estimated 600 million cases of foodborne illnesses around the world [149,150]. The mentioned disorders are primarily caused by biological contaminants present in food, which can be organisms such as parasites, microorganisms such as fungi and bacteria or viruses [151].

Among biological food hazards, bacteria are the most recurrent cause of disease [152], with Salmonella species, Campylobacter jejuni and Escherichia coli some of the most commonly involved foodborne pathogens $[3,153]$. The detection of these microorganisms is typically carried out via culture and colony counting, polymerase chain reaction (based on the amplification and quantification of the microorganism's DNA) and immunology-based 
methods [154-157]. The disadvantages of these strategies are that colony counting can be highly time-consuming and error-prone, while polymerase chain reaction methods usually require expensive equipment and reactants as well as specialized technical skills for performing them $[158,159]$. Finally, immunology techniques may require from hours to days to provide a result [160].

Certain types of bacteria are able to produce toxins, molecules that are also secondary metabolites of some fungi and represent a food safety hazard [161-163]. Their adverse health effects can vary; while some toxins such as staphylococcal can cause enteric illness, aflatoxins (produced by fungi) are known for being carcinogenic [164,165]. The detection of these agents is thus crucial for preventing foodborne outbreaks. Typically, these biological derived contaminants are detected via protocols that consists of time consuming extraction from the food matrix followed by pre-concentration steps and liquid or gas chromatography for their quantification [166].

Foodborne viruses are capable of infecting intestinal cells and are shed in the stool [167]. Noroviruses and Hepatitis A are the most common cause of viral foodborne disease, causing gastroenteritis and hepatitis, respectively [168]. Typically, they are detected by the scanning of a stool suspension under an electron microscope. This protocol, however, is insensitive and labor-intensive [169]. Immunoassays are available for the detection of some viruses [170,171], as well as transcriptase-polymerase chain reaction [172,173]. Nonetheless, the drawbacks of these techniques have been already discussed.

New technologies have been developed to overcome the disadvantages of analytical methods for biological food hazards detection. Imprinted polymers have been extensively researched for the extraction of toxins, which has also led to the application of these synthetic receptors in sensors [174-177]. Furthermore, bacteria detection using IPs in sensing devices has also been exploited [28,30,178-180]. The use of synthetic receptors as recognition element in food safety sensing exhibits the potential of becoming a fast, sensitive and cost-effective technology in contrast to the traditional analytical methods [181-183].

\subsection{Imprinting Technology for the Recognition of Biological Food Hazards}

As mentioned above, the affinity of imprinted polymers relies on a combination of functionality and geometry between the targeted analyte and the receptor. In the recognition of biological targets, geometry plays a crucial role in the selection of the material to be employed for IP preparation. While some biological analytes allow the use of classical molecularly imprinting strategies due to their small sizes and low molecular weights (e.g., toxins and viruses), larger ones represent a challenge. Bacteria, for instance, are microorganisms with dimensions up to several microns depending on the taxonomic groups [184]. To ensure these template's removal and rebinding, the synthesis of the receptor should allow the surface imprinting of the material [185].

This section is subdivided into the biological food hazards categories that have been detected using IPs. A summary of these agents, as well as the exemplification of the imprinting technologies employed for their recognition in food samples, is discussed.

\subsubsection{Toxins}

The most straightforward method of detecting microbial contamination in food is the detection of the toxins they produce as, these are often relatively small molecules which makes it possible to detect them with MIPs (Table 4). Sergeyeva et al. created functional polymeric membranes that functioned as synthetic receptors for the mycotoxin Aflatoxin B1. Ethyl-2-oxocyclopentanecarboxylate was employed as dummy template in the preparation of the imprinted materials, which were obtained via the photo-polymerization of diverse monomers between two glass slides. From the tested building blocks, 2-acrylamido-2methyl-1-propanosulfonic acid and acrylamide exhibited optimal performance for the recognition of the toxin. Recoveries of the analyte from the real samples wheat and maize flower ranged $87-96 \%$. The prepared membranes were further assessed as recognition element in a sensing device, which attained an LoD of $20 \mathrm{ng} / \mathrm{mL}$ [186]. 
Turan et al. made use of imprinted magnetic particles for the detection of ochratoxin A mycotoxin. For the preparation of the IPs, $\mathrm{Fe}_{3} \mathrm{O}_{4}$ nanoparticles were synthesized and surface-modified in order to act as polymerization initiators. Oligo(ethylene glycol) monomethyl ether methacrylate and ethylene glycol dimethacrylate were then polymerized from the particles in the presence of the template (Figure 3). The receptor was tested on spiked grape juice samples, observing a recovery of $97.1-97.5 \%$. Additionally, sensing of the toxin was reported to be possible from $0.374 \mu \mathrm{g} \mathrm{mL}^{-1}$. Selectivity of the IP was tested using aflatoxin and vomitoxin as competitive mycotoxins, for which they observed lower adsorption capacities in comparison to the targeted ochratoxin A [187].

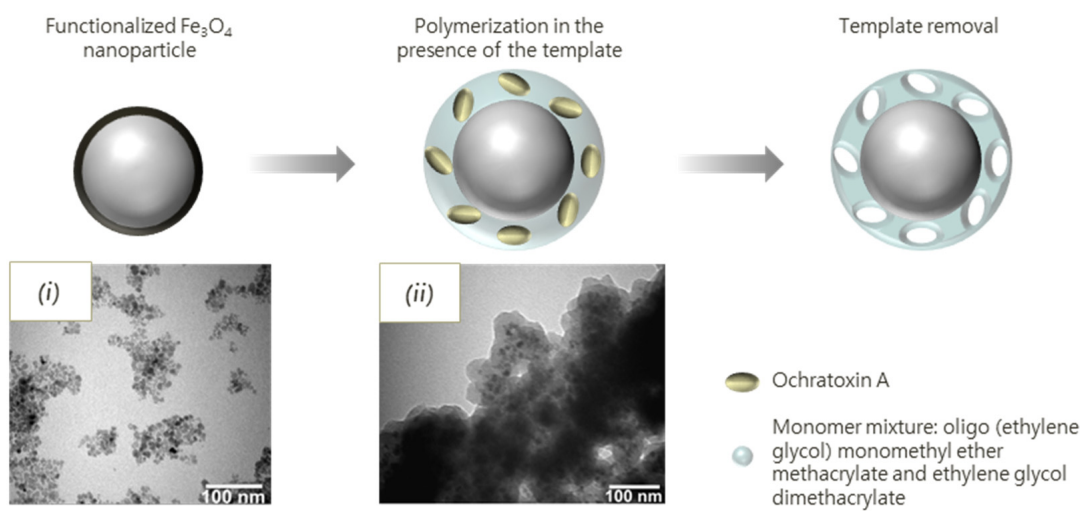

Figure 3. Schematic representation of synthesis of imprinted polymer on magnetic nanoparticles surface. TEM images of: (i) functionalized nanoparticles; and (ii) imprinted polymer magnetic nanoparticles. Reprinted from [187]. Copyright (2016), with permission from Elsevier.

Table 4. Summary of recent publications for the recognition of toxins using IPs in food samples.

\begin{tabular}{|c|c|c|c|c|c|c|}
\hline Analyte (s) & $\begin{array}{l}\text { Template/ } \\
\text { Monomer(s)/ } \\
\text { Crosslinker }\end{array}$ & IP Preparation & Food Sample & LoD & $\begin{array}{l}\text { Readout } \\
\text { Technique }\end{array}$ & Ref. \\
\hline $\begin{array}{c}\text { Staphylococcal } \\
\text { enterotoxins } \\
\text { A,B }\end{array}$ & $\begin{array}{l}\text { S. enterotoxin } \\
\text { B/APTES, } \\
\text { OTES/TEOS }\end{array}$ & Sol-gel & Milk & $7.97 \mathrm{ng} / \mathrm{mL}$ & Acoustic wave & $\begin{array}{l}{[188,} \\
189]\end{array}$ \\
\hline Patulin & $\begin{array}{c}\text { 2-oxin/ } \\
\text { APTES/TEOS }\end{array}$ & Sol-gel & $\begin{array}{l}\text { Apple and pear } \\
\text { juice, haw } \\
\text { flakes }\end{array}$ & $3.1 \times 10^{-3} \mu \mathrm{g} / \mathrm{mL}$ & Acoustic wave & [190] \\
\hline Patulin & $\begin{array}{c}\text { 2-oxindole/ } \\
\rho \text {-aminothiophenol }\end{array}$ & $\begin{array}{l}\text { Electrochemical: } \\
\text { Deposition }\end{array}$ & Apple juice & $7.57 \times 10^{-13} \mathrm{~mol} / \mathrm{L}$ & Electrochemical & [191] \\
\hline Patulin & $\begin{array}{l}\text { 6-Hydroxynicotinic } \\
\text { acid/ APTES/TEOS }\end{array}$ & Sol-gel & Apple juice & $0.32 \mu \mathrm{mol} / \mathrm{L}$ & Optical & [192] \\
\hline Ochratoxin A & $\begin{array}{l}\text { Ochratoxin A/ } \\
\text { Pyrrole }\end{array}$ & $\begin{array}{l}\text { Electrochemical: } \\
\text { Deposition }\end{array}$ & Beer and wine & $0.0041 \mu \mathrm{M}$ & Electrochemical & [193] \\
\hline Ochratoxin A & $\begin{array}{c}\text { Ochratoxin A/ } \\
\text { OEGMA/EGDMA }\end{array}$ & $\begin{array}{l}\text { Thermal: From } \\
\text { MNP surface }\end{array}$ & Grape juice & $0.374 \mu \mathrm{g} / \mathrm{mL}$ & UV-Vis & [187] \\
\hline Zearalenone & Zearalenone/Pyrrole & $\begin{array}{l}\text { Electrochemical: } \\
\text { Deposition }\end{array}$ & Corn & $0.3 \mathrm{ng}^{-1}$ & Optical & [194] \\
\hline Zearalenone & $\begin{array}{l}\text { CDHB/MAA/ } \\
\text { EGDMA }\end{array}$ & Thermal: Solution & $\begin{array}{l}\text { Corn, rice and } \\
\text { wheat flour }\end{array}$ & $0.002 \mu \mathrm{mol} / \mathrm{L}$ & Optical & [195] \\
\hline Deoxynivalenol & $\begin{array}{c}\text { Deoxynivalenol/ } \\
\text { o-phenylenediamine }\end{array}$ & $\begin{array}{l}\text { Electrochemical: } \\
\text { Deposition }\end{array}$ & Corn & $0.3 \mathrm{ng} / \mathrm{mL}$ & Electrochemical & [196] \\
\hline Aflatoxin B1 & $\begin{array}{l}\text { ethyl-2-OPC/AA, } \\
\text { allylamine, DEAEM, } \\
\text { MBAA, AMPSA }\end{array}$ & $\begin{array}{l}\text { Photo: Solution, } \\
\text { semi- } \\
\text { interpenetrating } \\
\text { networks }\end{array}$ & Maize flour & $20 \mathrm{ng} / \mathrm{mL}$ & Optical & [186] \\
\hline
\end{tabular}

APTES, (3-aminopropyl) triethoxysilane; TEOS, Tetraethyl orthosilicate; OTES, Triethoxy (octyl) silane; OEGMA, oligo (ethylene glycol) monomethyl ether methacrylate; EGDMA, ethylene glycol dimethacrylate; OPC, oxocyclopentanecarboxylate; DEAEM, 2-(diethylamino) ethyl methacrylate; AMPSA, 2-acrylamido-2-methyl-1-propansulfonic acid; MBAA, N,N'-methylenebisacrylamide. 
The results in Table 4 are in line with the findings described in Section 3, which makes sense as toxins are typically low-molecular weight molecules similar to drugs, pesticides or hormone disruptors. Electro-deposition is again demonstrated to be a very interesting and well-researched approach due to its scalability and its combination with electrochemical transducers leading to sensitive sensor platforms.

\subsubsection{Bacteria}

The detection of whole bacterial cells was demonstrated on several occasions over the past few years. In 2019, Zhao et al. used a Pickering emulsion polymerization approach for imprinting polymers with Listeria monocytogenes. The reaction mixture consisted of an oil-water system, in which the aqueous phase contained a bacteria-chitosan network, prepared with acryloyl-functionalized chitosan and quantum dots (CdTe). On the other hand, the oil phase contained the monomers (trimethylolpropane trimetharylate, N,Ndimethylaniline and divinylbenzene) and the initiator. Solid polymer beads with imprints on the surface were obtained, as can be seen in Figure 4. To assess the adsorption of the particles, binding experiments were performed, from which the adsorption capacities of the IP (355.6 CFU mg ${ }^{-1}$ ) exhibited a 4.5-fold increase in comparison to the non-imprinted polymers. Regarding the limit of detection, the sensor achieved a performance of $1 \times 10^{3}$ colony forming units per milliliter. Furthermore, selectivity against $S$. aureus was visually confirmed. Application to real samples was carried out by inoculating milk and pork with the bacteria, homogenizing with the IPs and sedimenting for $3 \mathrm{~min}$ [197].
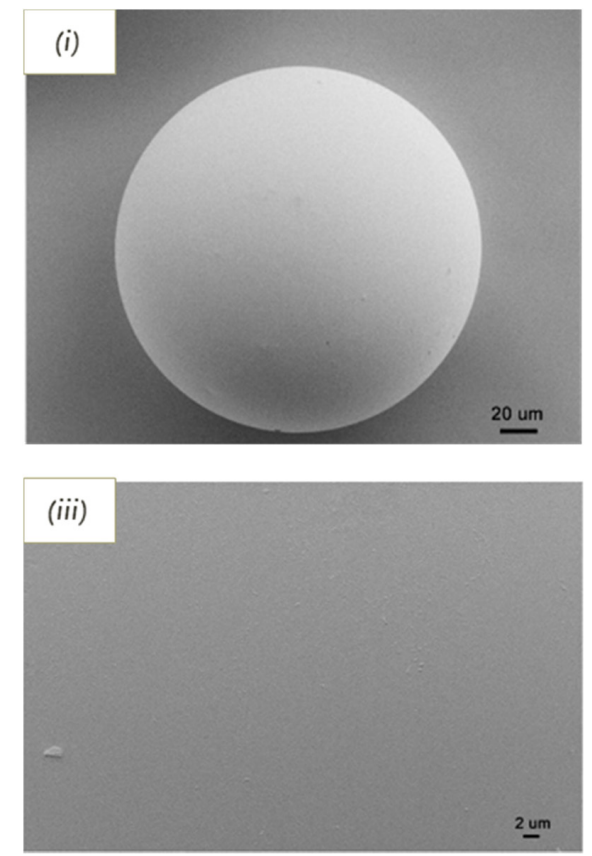
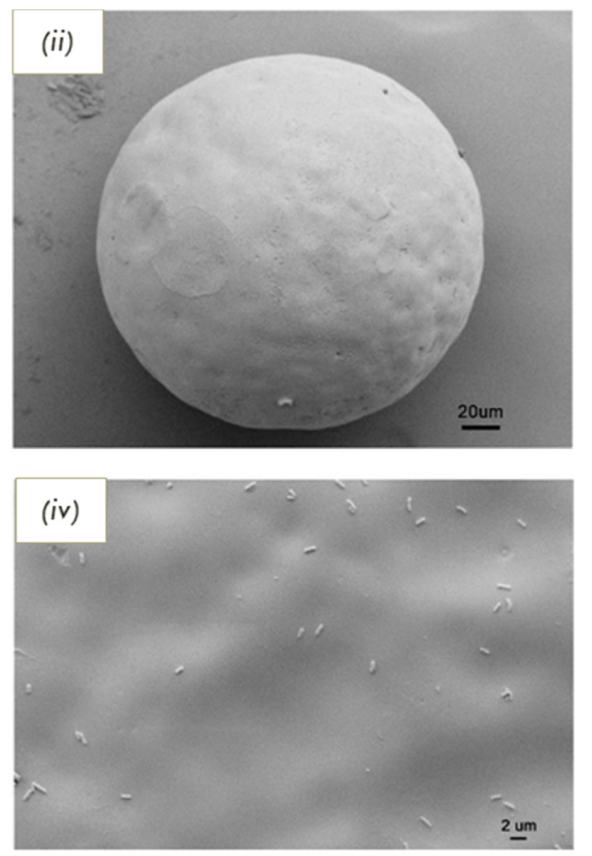

Figure 4. Scanning electron microcopy (SEM) images of (i) non-Imprinted particle and (ii) imprinted particle; and corresponding magnified images of (iii) non-imprinted and (iv) imprinted beads. Figure adapted from [197] with permission under open-access copyright agreement.

Cornelis et al. took a different approach in the construction of their bacterial sensor. They made synthetic E. coli receptors by micro-contact imprinting. The monomers employed were bisphenol A, phloroglucinol and 4, 4'-diisocyanatodiphenylmethane, which were partially polymerized before spin coating solid substrates. The surface imprinting of these polymers was performed with polydimethylsiloxane bacterial stamps. After full curing of the films in the presence of the template, functionalized polyurethane films were obtained. The films were incorporated into a sensing platform, which was able of detecting $1 \times 10^{2} \mathrm{CFU} \mathrm{mL}{ }^{-1}$. Cross-sensitivity was assessed with four coliform species of 
the Enterobacteriaceae family and the receptor was further tested with non-cleared spiked apple juice samples [198].

Tokonami et al. achieved recognition of Pseudomonas aeruginosa by preparing an IP via the electropolymerization of pyrrole (Figure 5). The constant potential electrodeposition of the polymer was performed in phosphate buffer using a quartz crystal microbalance electrode as deposition substrate, same that was employed as sensor component for measurements of the bacteria in apple juice. The receptors, besides recognizing P. aeruginosa with a LoD of $1 \times 10^{3} \mathrm{CFU} \mathrm{mL}{ }^{-1}$, were able to discriminate the analyte against $E$. Coli and other bacterial species [80].
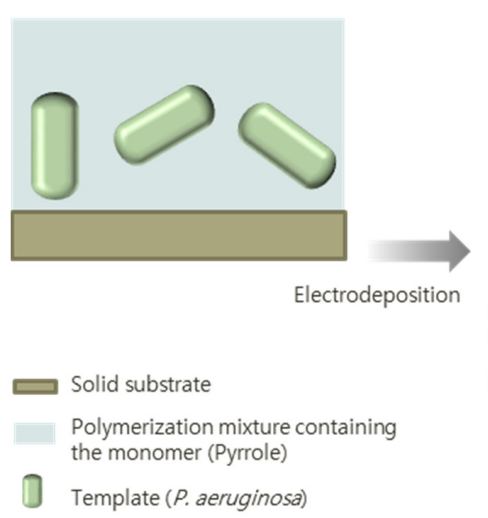
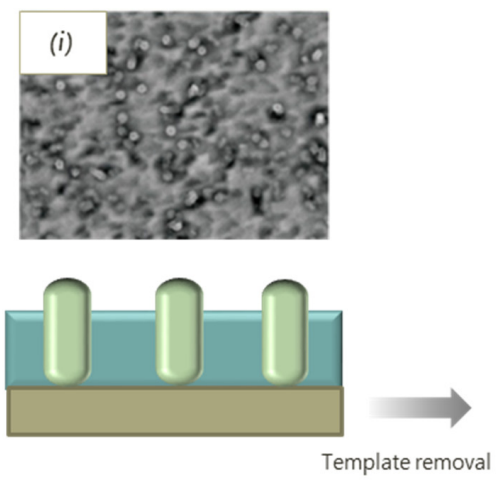
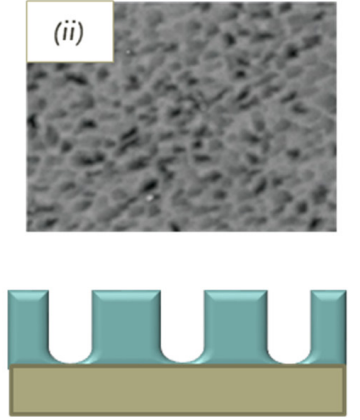

Figure 5. Schematic representation of polypyrrole imprinting with bacteria. SEM images of: (i) imprinted polypyrrole; and (ii) polypyrrole film with bacteria cavities. Reprinted (adapted) with permission from [80]. Copyright (2013) American Chemical Society.

A summary of publications reporting on bacterial recognition employing IPs can be found in Table 5. As bacteria are whole-cell microorganisms, they require a different approach as compared to the sensor systems described above for small molecules. Although it is possible to use emulsion polymerization in MIP-like fashion [197], most platforms are based on SIP-based detection. Micro-contact imprinting offers the possibility of creating proof-of-concept platforms with surprisingly low detection limits, but upscaling would require a highly advanced roll-to-roll coating device. Electro-deposition in this sense is a valuable alternative leading to ultra-sensitive detection of bacteria in solution but requires voltammetry parameter optimization and is mainly interesting for electrochemical detection, while micro-contact imprinting is more broadly combinable with other readout technologies.

Table 5. Summary of recent publications for the recognition of bacteria using IPs in food samples.

\begin{tabular}{|c|c|c|c|c|c|c|}
\hline Analyte (s) & $\begin{array}{c}\text { Template/Monomer(s)/ } \\
\text { Crosslinker }\end{array}$ & IP Preparation & $\begin{array}{c}\text { Food } \\
\text { Sample }\end{array}$ & LoD & $\begin{array}{l}\text { Readout } \\
\text { Technique }\end{array}$ & Ref. \\
\hline $\begin{array}{c}\text { Listeria } \\
\text { monocytogenes }\end{array}$ & $\begin{array}{l}\text { L. monocytogenes/ } \\
\text { TRIM/DMA }\end{array}$ & $\begin{array}{l}\text { Thermal: Pickering } \\
\text { emulsion }\end{array}$ & $\begin{array}{l}\text { Milk, } \\
\text { pork }\end{array}$ & $1 \times 10^{3} \mathrm{CFU} / \mathrm{mL}$ & Optical & [197] \\
\hline Salmonella paratyphi & $\begin{array}{c}\text { S. paratyphi/ } \\
\text { MAH/EGDMA }\end{array}$ & $\begin{array}{c}\text { Photo: } \\
\text { Micro-contact }\end{array}$ & Apple & $1.4 \times 10^{6} \mathrm{CFU} / \mathrm{mL}$ & Optical & [199] \\
\hline Escherichia coli & $\begin{array}{c}\text { E. coli/MAH, } \\
\text { HEMA/EGDMA }\end{array}$ & $\begin{array}{c}\text { Photo: } \\
\text { Micro-contact }\end{array}$ & $\begin{array}{l}\text { Apple } \\
\text { juice }\end{array}$ & $1.5 \times 10^{6} \mathrm{CFU} / \mathrm{mL}$ & $\begin{array}{c}\text { Optical/ } \\
\text { Acoustic wave }\end{array}$ & [200] \\
\hline Escherichia coli & $\begin{array}{c}\text { E.coli } / 4,4^{\prime}-\mathrm{MDI}, \\
\text { PG/BPA }\end{array}$ & $\begin{array}{c}\text { Thermal: } \\
\text { Micro-contact }\end{array}$ & $\begin{array}{l}\text { Apple } \\
\text { juice }\end{array}$ & $1 \times 10^{2} \mathrm{CFU} / \mathrm{mL}$ & Thermometric & [198] \\
\hline Escherichia coli & E. coli/Dopamine & $\begin{array}{l}\text { Electrochemical: } \\
\text { Deposition }\end{array}$ & Water & $8 \mathrm{CFU} / \mathrm{mL}$ & $\begin{array}{l}\text { Electrochemical/ } \\
\text { optical }\end{array}$ & [77] \\
\hline $\begin{array}{l}\text { Pseudomonas } \\
\text { aeruginosa }\end{array}$ & P. aeruginosa/Pyrrole & $\begin{array}{l}\text { Electrochemical: } \\
\text { Deposition }\end{array}$ & $\begin{array}{l}\text { Apple } \\
\text { juice }\end{array}$ & $1 \times 10^{3} \mathrm{CFU} / \mathrm{mL}$ & Electrochemical & [80] \\
\hline
\end{tabular}

TRIM, Trimethylopropane trimethacrylate; DMA, N, N-dimethylaniline; MAH, acrylate N-methacryloyl L-histidine methyl ester; EGDMA, ethylene glycol dimethacrylate; 4,4'-MDI, Diisocyanatodiphenylmethane; PG, Phloroglucinol; BPA, Bisphenol A. 


\subsubsection{Viruses}

To our knowledge, Yang et al. are the only group to report on the recognition of a virus in terms of food safety. In this research, silica nanoparticles were synthesized and used for molding imprinting of hepatitis A. Self-polymerization of the monomer (dopamine) was carried out in Tris buffer (Figure 6). The obtained imprinted particles were tested in human serum, from which they obtained recoveries in the range of $94-96 \%$. The spherical IP proved to be able of sensing the analyte with a LoD of $8.6 \mathrm{pmol}$ per liter. Moreover, selective recognition against other viruses (rubella, rabies and measles) viruses was performed [201].

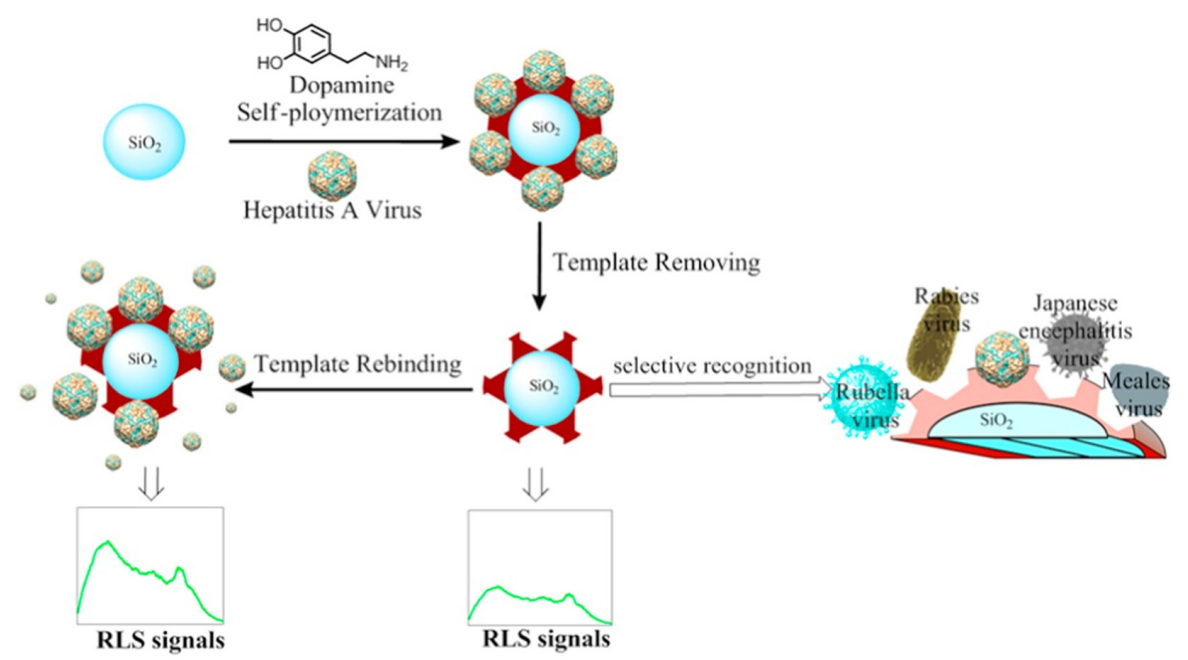

Figure 6. Schematic representation of the preparation of Hepatitis A-imprinted poly(dopamine). Reprinted from [201]. Copyright (2017), with permission from Elsevier.

\section{The Role of Transducers in Designing a Sensor for Application in Food Safety}

In the previous sections, we mainly focus on the different potential contaminants and how different imprinting strategies can be exploited to create sensitive receptors for both sensing and separation/purification purposes. When constructing integrated sensor devices, however, the transducer principle used is equally important to the receptor design as the sensitivity of a sensor depends on both the recognition element and the transducer. The transducer possesses the key role of converting the recognition event into a measurable signal, typically proportional to the number of interactions between the analyte and the receptor (Figure 7) [37,202]. In this section, we describe the most representative readout techniques that have been combined with IPs in the detection of chemical and microbiological food contaminants.

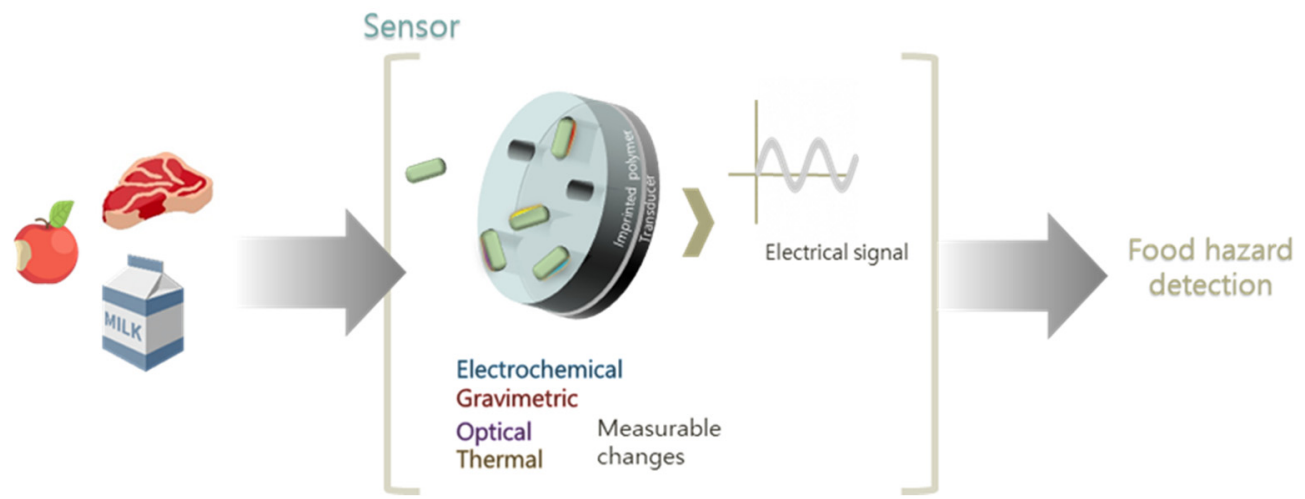

Figure 7. Imprinted polymers coupling to transducers for food safety application. 


\subsection{Electrochemical Detection}

Sensors based on electrochemical transducers are the most frequently reported in biosensing applications due to their relatively high sensitivity and selectivity at a low cost $[203,204]$. The possibility of miniaturization and the suitability that these platforms possess for being used in complex matrices are two additional key advantages for food analysis [205]. In this regard, IPs have been coupled with electrochemical transducers to sense food safety hazards. Upon the binding of the specific targets to the receptor, electrical changes are observed. These changes can be amperometric/voltammetric (in currents) or potentiometric (in potentials or accumulated charge). Additionally, impedimetric changes (in resistance or capacity) have also been researched [206]. Since electrochemical transducers rely on measurable electrical changes, the electron transfer ability between the recognition sites of the receptor and the surface of the electrode employed determines the sensitivity of the sensor [207]. Therefore, conductive materials such as conjugated polymers or conductive additives as nanoparticles (carbon, gold, etc.) are typical components of these platforms.

For example, Bougrini et al. used voltammetry to quantify tetracycline, using an imprinted layer composite of poly(thioaniline) and gold nanoparticles onto a gold electrode for the measurements. The sensor attained a limit of detection of $0.22 \mathrm{fM}$ and was successfully tested on honey samples, proving the suitability of the sensor in complex food matrices [208]. Apart of high sensitivity, rapid detection is a desirable characteristic in sensors for food safety, where toxin accumulation during time poses a risk. This challenge was addressed by Idil et al. for the real time detection of E. coli, using a capacitive transducer coupled to a vinyl based imprinted polymer onto a gold electrode. This sensor yielded a detection limit of $70 \mathrm{CFU} / \mathrm{mL}$ and was tested on apple juice samples (Figure 8) [209]. Other related publications that cover electrochemical platforms coupled to imprinted polymers are summarized in Table 6.
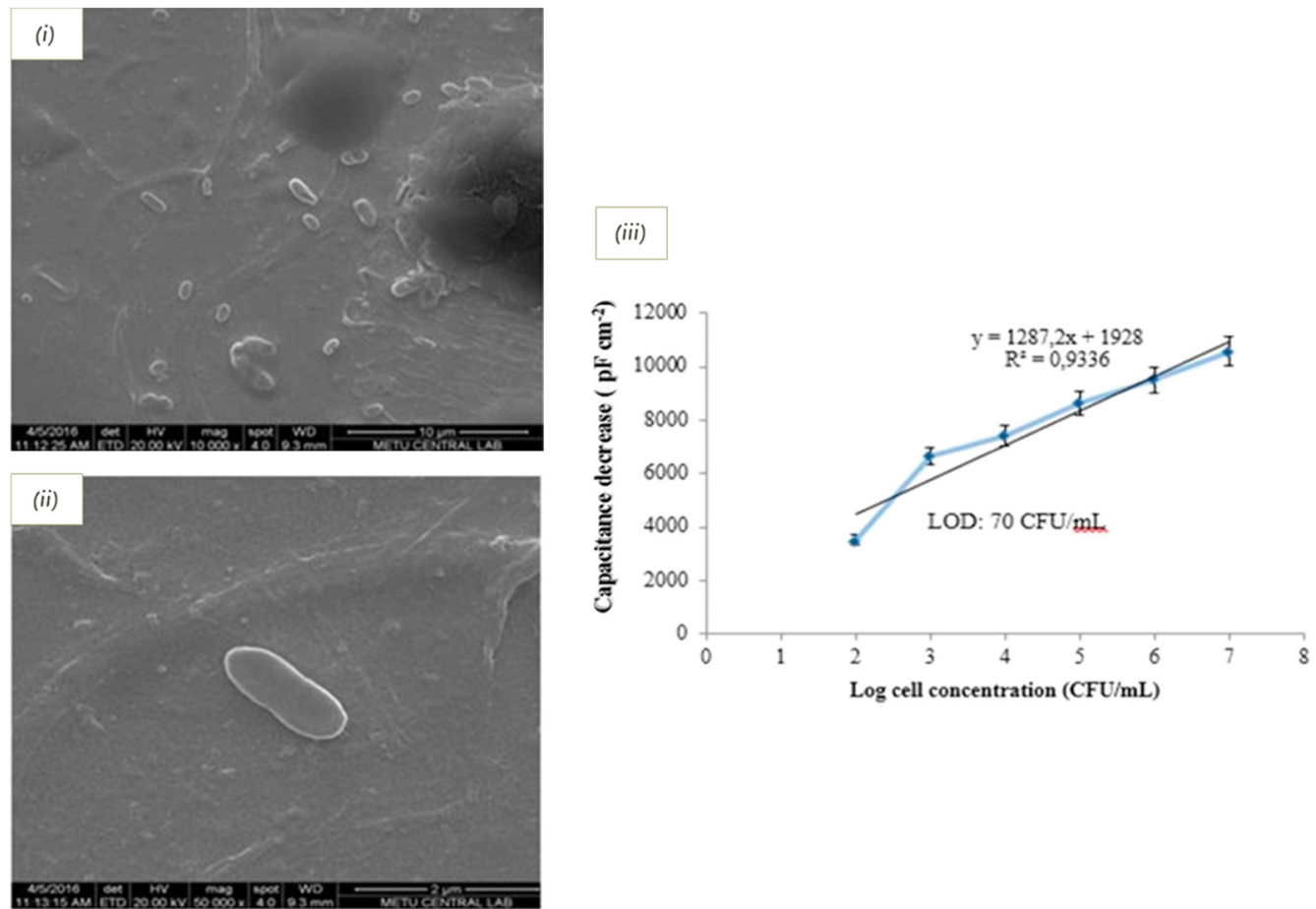

Figure 8. Electrochemical detection of Escherichia coli: (i,ii) SEM images of bacteria imprinted electrodes; and (iii) calibration curve obtained from the capacitive response of the electrode towards the analyte. Reprinted from [209]. Copyright (2017), with permission from Elsevier. 
Table 6. Imprinted polymer-electrochemical sensors for food safety.

\begin{tabular}{|c|c|c|c|c|c|}
\hline Analyte & $\begin{array}{l}\text { Sensor Composition } \\
\text { IP/Electrode }\end{array}$ & Food Sample & $\begin{array}{c}\text { Limit of } \\
\text { Detection }\end{array}$ & $\begin{array}{l}\text { Response } \\
\text { Time }\end{array}$ & Ref. \\
\hline Melamine & Poly (aniline-co-acrylic acid)/GCE & Milk & $17.2 \mathrm{pM}$ & $20 \mathrm{~min}$ & [210] \\
\hline Phosalone & Poly (APTES-co-TEOS)/Pt-UiO-66,CPME & $\begin{array}{l}\text { Lake water, soil, wheat, } \\
\text { cucumber orange }\end{array}$ & $78 \mathrm{pM}$ & $2 \mathrm{~min}$ & [114] \\
\hline Carbendazim & $\operatorname{Poly}\left(\mathrm{O}\right.$-phenylenediamine)/S- $\mathrm{Mo}_{2} \mathrm{C}, \mathrm{GCE}$ & $\begin{array}{l}\text { Grape, apple, tomato, } \\
\text { eggplant, cucumber }\end{array}$ & $0.67 \mathrm{pM}$ & $6 \mathrm{~min}$ & [117] \\
\hline Tetracycline & Poly $(P$-aminothiophenol $) / A u$ & Honey & $0.22 \mathrm{fM}$ & $30 \mathrm{~min}$ & [208] \\
\hline Melamine & Polyaniline, $\mathrm{Au} / \mathrm{GCE}$ & Milk, feed & $1.39 \mathrm{pM}$ & $40 \mathrm{~min}$ & [211] \\
\hline Diethylstilbestrol & $\begin{array}{c}\text { Poly (APTES-co-TEOS co-OTOMS)/AuNP, } \\
\text { MWCNT, GCE }\end{array}$ & Milk & $24.3 \mathrm{fg} / \mathrm{mL}$ & $15 \mathrm{~min}$ & [212] \\
\hline Fumonisin B1 & Poly (MAA-co-EGDMA)/GO-CdS, ITO & Milk, maize meal & $4.7 \mathrm{pg} / \mathrm{mL}$ & $15 \mathrm{~min}$ & [213] \\
\hline Fumonisin B1 & $\begin{array}{l}\text { Poly (MAA-co-EGDMA)/ } \mathrm{Ru}, \mathrm{SiO}_{2}, \mathrm{CS}, \mathrm{Au} \\
\text { NP, GCE }\end{array}$ & Milk, maize meal & $0.35 \mathrm{pg} / \mathrm{mL}$ & $15 \mathrm{~min}$ & [214] \\
\hline Escherichia coli & Poly (MAH-co-HEMA-co-EGDMA)/Au & Apple juice & $70 \mathrm{CFU} / \mathrm{mL}$ & Real-time & [209] \\
\hline
\end{tabular}

GCE, Glassy carbon electrode; APTES, (3-aminopropyl)triethoxysilane, TEOS, Tetraethyl orthosilicate; Pt-UiO-66, metal-organic framework catalyst; CPME, Carbon paste microelectrode; Au, gold; SG, Sulfonated graphene; MWCNT, Multi-walled carbon nanotubes; OTOMS, Octyltriethoxysilane; MAA, Methacrylic acid; SPE, Screen printed electrode; CS, Chitosan; NP, Nanoparticles; EGDMA, Ethylene glycol dimethacrylate; GO, Graphene oxide; ITO, Indium tin oxide; MAH, N-methacryloyl-L-histidine methylester; HEMA, 2-Hydroxyethyl methacrylate.

\subsection{Optical Detection}

The core process of these sensors is the conversion of optical properties (e.g., photons) into an electronic signal, related to a receptor-target binding event. Reports of IP sensors exploit optical properties such as refractive index, optical absorbance or fluorescence [215]. Other well-known examples of optical biosensing platforms include Surface Plasmon Resonance (SPR) and Surface Enhanced Raman Scattering (SERS). In terms of MIPs and food hazards detection, fluorescence and SPR are the most investigated readout platforms (Table 7).

Fluorescence is often used due to its simplicity and high sensitivity. Sensors based on fluorescence, however, present the drawback of requiring a label when the analyte does not possess intrinsic optical properties (e.g., absorption or photoluminescence). One of the most representative fluorescent labels are quantum dots (QD), which can be incorporated into the synthetic receptor to enable the use of this readout method [36,216]. An example within food hazard detection is the sensor employed by Liu et al. for methamidophos, a pesticide. The imprinted polymeric receptor is based on methacrylic acid, ethylene glycol methacrylate and QDs as label. The obtained fluorescent probe showed a limit of detection of $0.092 \mu \mathrm{M}$, and the setup was tested on real food matrices such as apples and pears [217].

Under specific incident light illumination, SPR measures changes in the refractive index of a medium near a metal surface (e.g., Au or Ag). This optical phenomenon is exploited for biosensing, where receptors are immobilized on the surface. Upon binding to their specific targets, a change in mass will be observed and, thus, a change in refractive index that can be analyzed in real time $[218,219]$. Zhang et al. demonstrated the use of an SPR biomimetic sensor for the detection for the antibiotic kanamycin in 2018. They obtained a limit of detection of $0.043 \mu \mathrm{M}$ in complex food samples, e.g. milk and honey [220].

Table 7. Imprinted polymer-optical sensors for food safety.

\begin{tabular}{|c|c|c|c|c|c|}
\hline Analyte & $\begin{array}{l}\text { Sensor Composition } \\
\text { IP/Electrode }\end{array}$ & Food Sample & Limit of Detection & $\begin{array}{l}\text { Response } \\
\text { Time }\end{array}$ & Ref. \\
\hline Kanamycin & $\begin{array}{l}\text { Poly 4-vinylphenylboronic } \\
\text { acid-co-PEGDA) }\end{array}$ & $\begin{array}{l}\text { Milk, } \\
\text { honey }\end{array}$ & $\begin{array}{l}0.0433 \mu \mathrm{M} \\
0.0120 \mu \mathrm{M}\end{array}$ & - & [220] \\
\hline Methamidophos & Poly (MAA-co-EGDMA),QD & $\begin{array}{l}\text { Apple, pear, kidney } \\
\text { bean, leek, cucumber }\end{array}$ & $0.0916 \mu \mathrm{M}$ & $3 \mathrm{~h}$ & [217] \\
\hline Escherichia coli & Poly(HEMA-co-EGDMA-co-MAH) & Apple juice & $1.54 \times 10^{6} \mathrm{CFU} / \mathrm{mL}$ & $113 \mathrm{~s}$ & [200] \\
\hline
\end{tabular}

PEGDA, Poly (ethylene glycol) diacrylate; MAA, Methacrylic acid; EGDMA, Ethylene glycol dimethacrylate; QD, Quantum dots; MAH, N-methacryloyl-L-histidine methylester; HEMA, 2-Hydroxyethyl methacrylate. 


\subsection{Acoustic Wave Transducers}

As these sensors detect small changes in mass, they are also known as mass-sensitive sensors. They typically comprise a piezoelectric crystal, onto which the receptors (in this case, imprinted polymers) are immobilized. The crystal will vibrate at a certain frequency under the influence of an electrical field, achieving resonance at a very high frequency. When the target binds to the receptor, it will produce a measurable change in the crystal's vibration frequency. This change correlates with the added mass on the crystal surface [221]. Some of its advantages lie in the possibility to perform several assay formats as well as on-line analysis of receptor-target interactions [219]. Nevertheless, the relatively long incubation times required as well as the number of washing and drying steps can be drawbacks in terms of application for food safety.

There are two major types of mass-based biosensors: Bulk Acoustic Wave (BAW) and Surface Acoustic Wave (SAW) devices. BWV is also known as Quartz Crystal Microbalance (QCM), and, as shown in Table 8, it is the piezoelectric transducer most exploited for the detection of food safety hazards of both chemical and microbiological nature in real samples. Some of these sensor platforms have been proven to be very sensitive and highly interesting for application in food safety screening (Table 8). Yola et al., for example, used a QCM-based biomimetic sensor for the real-time detection of the antibiotic tobramycin in chicken egg white and milk in concentrations in the low picomolar concentration range (Figure 9) [222].

Table 8. Imprinted polymer-piezoelectric sensors for food safety.

\begin{tabular}{|c|c|c|c|c|c|c|}
\hline Transducer & Analyte & $\begin{array}{l}\text { Sensor Composition } \\
\text { IP/Electrode }\end{array}$ & Food Sample & Limit of Detection & $\begin{array}{l}\text { Response } \\
\text { Time }\end{array}$ & Ref. \\
\hline$S P R / Q C M$ & Escherichia coli & $\begin{array}{c}\text { Poly(HEMA-co-EGDMA-co- } \\
\text { MAH) }\end{array}$ & Apple juice & $3.72 \times 10^{5} \mathrm{CFU} / \mathrm{mL}$ & $56 \mathrm{~s}$ & [200] \\
\hline$S P R$ & Tobramycin & Poly (HEMA-co-MAGA) & $\begin{array}{l}\text { Chicken egg } \\
\text { white, milk }\end{array}$ & $5.7 \mathrm{pM}$ & Real time & [222] \\
\hline QCM & Methimazole & Poly(MAA-co-EGDMA),silica & $\begin{array}{l}\text { Pork, beef and } \\
\text { milk }\end{array}$ & $3 \mu \mathrm{g} / \mathrm{L}$ & $8 \mathrm{~min}$ & [25] \\
\hline QCM & Estradiol & $\begin{array}{c}\text { Poly (MAA-co- } \\
\text { Vinylpyrollidone-DHEBA) }\end{array}$ & Bread & $2 \mu \mathrm{g} / \mathrm{L}$ & $5-10 \mathrm{~min}$ & [23] \\
\hline QCM & $\begin{array}{l}\text { Trichlorfon } \\
\text { (TCF) }\end{array}$ & Poly (Vinylidene difluoride) & Lettuce & $15.77 \mathrm{ppb}$ & $6 \mathrm{~h}$ & [115] \\
\hline QCM & Metolcarb & Poly(MAA-co-EGDMA) & $\begin{array}{l}\text { Apple juice, } \\
\text { pear, cabbage }\end{array}$ & $2.309 \mu \mathrm{g} / \mathrm{L}$ & $12 \mathrm{~min}$ & [112] \\
\hline
\end{tabular}

PEGDA, Poly (ethylene glycol) diacrylate; MAA, Methacrylic acid; EGDMA, Ethylene glycol dimethacrylate; QD, Quantum dots; MAH, N-methacryloyl-L-histidine methylester; HEMA, 2-Hydroxyethyl methacrylate.

(i)

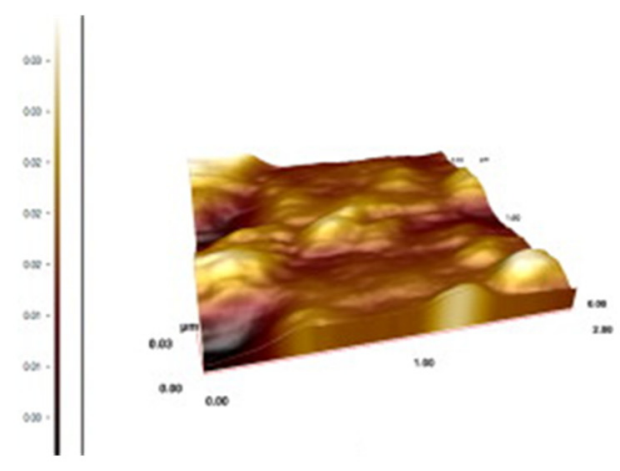

(ii)

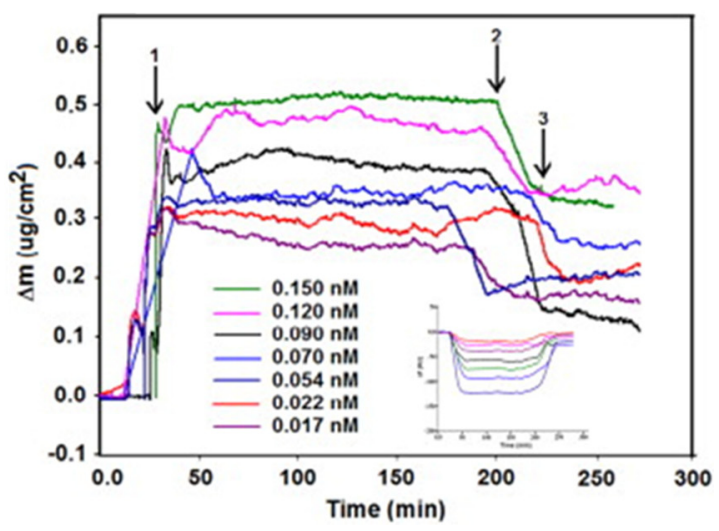

Figure 9. QCM detection of tobramycin using a molecularly imprinted polymer: (i) AFM image of MIP film. (ii) The effect of concentration on QCM response of target: (1) adsorption; (2) desorption; and (3) regeneration. Reprinted from [222]. Copyright (2014), with permission from Elsevier. 


\subsection{Thermometric: Heat Transfer Method}

A relatively novel class of transducer principles are thermal detection techniques. Traditionally, thermal sensing principles are usually based on calorimetry, but, in recent years, the Heat Transfer Method (HTM) has emerged as an interesting biosensing technique [10]. HTM monitors the thermal transport across a solid-liquid interface where the IP receptors are immobilized. Moreover, a temperature gradient is applied over the receptor layer which is monitored in time. The thermal resistance of the interface changes in function of the amount of target molecules bound to the receptor layer, blocking the heat flow through the interface and changing the gradient. It is a low-cost and homemade setup with a low detection limit (nM range) that has a wide range of applications. Additionally, it can be easily scaled down in terms of point-of-care sensing and any electrode that enables heat flow through IP layer can be incorporated into the device $[10,178,223]$.

In food hazard detection, the only report to our knowledge utilizing HTM as readout platform employs a polyurethane bacteria-imprinted layer (Table 9). The samples were tested on apple juice samples and sensor exhibited a low limit of detection of $100 \mathrm{CFU} / \mathrm{mL}$, which further emphasizes the application potential of the methodology.

Table 9. Imprinted polymer-thermometric sensors for food safety.

\begin{tabular}{cccccc}
\hline Analyte & $\begin{array}{c}\text { Sensor } \\
\text { Composition } \\
\text { IP/Electrode }\end{array}$ & Food Sample & $\begin{array}{c}\text { Limit of } \\
\text { Detection }\end{array}$ & Response Time & Ref. \\
\hline Escherichia coli & Polyurethane & Apple juice & $100 \mathrm{CFU} / \mathrm{mL}$ & Real time & {$[198]$} \\
\hline
\end{tabular}

\section{Outlook and Conclusions}

Currently, most industrial food plants still rely on external laboratories (some of them located abroad) for risk assessment of product's safety. These laboratories make use of highly sensitive but expensive and time-consuming bench detection technologies (e.g., gas chromatography, PCR, media-based metabolic tests, etc.). During the testing time, companies need to either store the product until the results are obtained or distribute and recall the product in case of hazard detection, which translates to extra costs. Furthermore, developing countries and rural areas have no access to these technologies [224]. Consequently, there is a high demand of cost-effective and robust analytical devices to monitor food safety on-site, which would enable effective prevention and control strategies at the different processing steps.

In this context, an on-site testing device that is Affordable, Sensitive, Specific, Userfriendly, Rapid and robust, Equipment free and Deliverable to end users (ASSURED) could have significant scientific and commercial impact [225]. IP-based technology is mainly interesting because of its affordable, user-friendly, robust nature and the fact it is equipment-free. The examples highlighted in the current review are often still in the laboratory phase of development, but, as technology becomes more advanced, they will get closer and closer to market penetration. In this respect, paper- and chip-based devices have gained a lot of interest as potential immobilization platforms for IPs in sensors that are able to detect food hazards in real samples. Paper-based platforms, for example, have been used for optical and thermal detection of pesticides, hormones and toxins [225-228] and are particularly interesting because of their low-cost, user-friendly mode of operation and equipment-free process. Another promising candidate for on-site testing are chipbased devices. They offer advantages such as small size, simplification of instruments, capability of multiplex assays, small amount of samples with precise control and high throughput analysis. They are a bit more expensive than paper-based assays, but they offer a higher degree of robustness. Chip-based devices have been combined with various read-out principles including colorimetric and SPR for the detection of the whole range of food contaminants, from drugs to insecticides and even whole-cell bacteria $[199,228,229]$. 
Devices such as these could accelerate the application of imprinting technology in the food-safety value chain from a technological perspective.

IPs also have a large benefit from a chemical and logistical perspective as they have an improved performance compared to their biological analogues in terms of shelf life, resistance to matrices ( $\mathrm{pH}$, ions, oxidizing conditions, etc.), LOD and response time. Additionally, traditional antibody-based sensors are more expensive because they require animals for the antibodies production. Animal storage, target compound isolation and purification, animal inoculation, purification and storage of the antibodies are all costs that IPs do not have. Therefore, the overall cost of producing IPs sensors is cheaper and it can be easily scaled up or down depending on the customers need. Despite these advantages and the fact that they are low-cost, user friendly-devices, no commercial IP-based sensors have been developed until date. One of the major issues yet to be overcome is the large-scale production of homogenous batches of IPs.

New advances in commercial MIP production could overcome this bottleneck in the future. Traditionally, commercial IP synthesis by big chemical companies such as Sigma-Aldrich mainly focuses on the development of IPs for separation purposes. In recent years, new players have entered the market such as MIP Diagnostics Ltd. They focus on designing homogenous batches of high-affinity MIPs specifically designed for biosensing. By collaborating with partners focusing on the integration of these MIPs in technically advanced readout platforms, huge steps towards valorization can be made in coming years [230,231]. Furthermore, in a globalized food chain, it has proven to be challenging to prevent foodborne outbreaks, and finally consumers are starting to get more interested in knowing how safe the food that they consume is. Easy IP-based test kits (e.g., colorimetric paper-based strips) could provide consumers more confidence in the food that they buy. IP technology can offer the consumer a way to accurately determine if their food is spoiled or contains compounds outside the regulatory limits, rather than having to trust the expiry date. In addition, such technology could also prevent food waste as a lot of food products are thrown away because the expiry date has passed while there might be nothing wrong with them. The work by Sergeyeva et al. illustrates what such a sensor might look like [186]; imprinted membranes can be designed for the detection of spoilage indicators and attached to food packaging. Rebinding of the indicator to the MIP membrane will then lead to a signal that the customer can read-out using, for instance, a smartphone. Similar studies further emphasize the potential impact of such a sensor on the food industry of the future $[232,233]$. In conclusion, further research on similar on-site IP-based test kits could lead to the development of smart sensing tools that are beneficial for every member belonging to the farm-to-fork production chain in coming decades.

Author Contributions: Conceptualization, R.A.-C. and K.E.; methodology, R.A.-C. and K.L.J.-M.; investigation, H.D., R.A.-C. and B.v.G.; resources, T.J.C., R.A.-C. and K.E.; writing-original draft preparation, R.A.-C., K.L.J.-M. and K.E.; writing-review and editing, H.D., T.J.C., B.v.G. and K.E.; visualization, R.A.-C. and K.L.J.-M.; supervision, K.E. and H.D.; project administration, T.J.C. and H.D.; funding acquisition, T.J.C., H.D., B.v.G. and K.E. All authors have read and agreed to the published version of the manuscript.

Funding: This research was financially supported by the European Regional Development Fund through the AgrEU food project, funded by the Interreg VA Flanders-The Netherlands program, CCI grant No. 2014TC16RFCB046.

Institutional Review Board Statement: Not applicable.

Informed Consent Statement: Not applicable.

Data Availability Statement: Not applicable.

Conflicts of Interest: The authors declare no conflict of interest. 


\section{References}

1. Garwood, P.; Gutierrez, D. More complex foodborne disease outbreaks require new technologies, greater transparency. Jt. News Release. 2019. Available online: https:/ /www.who.int/news/item/06-12-2019-more-complex-foodborne-disease-outbreaksrequires-new-technologies-greater-transparency (accessed on 20 December 2020).

2. WHO. WHO Estimates of the Global Burden of Foodborne Diseases: Foodborne Disease Burden Epidemiology Reference Group 2007-2015. 2015. Available online: https://www.who.int/activities/estimating-the-burden-of-foodborne-diseases (accessed on 20 December 2020).

3. World Health Organization (WHO). Fact Sheets on Food Safety. 2015. Available online: https://www.who.int/news-room/factsheets/detail/food-safety (accessed on 20 December 2020).

4. Jaffee, S.; Henson, S.; Unnevehr, L.; Grace, D.; Cassou, E. The Safe Food Imperative: Accelerating Progress in Low and Middle-Income Countries; World Bank Group: Washington, DC, USA, 2018.

5. FAO/WHO. Codex Alimentarius Commission. Procedural Manual, 24th ed.; Joint FAO/WHO Publication: Rome, Italy, 2015.

6. Kamilaris, A.; Fonts, A.; Prenafeta-Boldv́, F.X. The rise of blockchain technology in agriculture and food supply chains. Trends Food Sci. Technol. 2019, 91, 640-652. [CrossRef]

7. Xu, M.-L.; Liu, J.-B.; Lu, J. Determination and control of pesticide residues in beverages: A review of extraction techniques, chromatography, and rapid detection methods. Appl. Spectrosc. Rev. 2014, 49, 97-120. [CrossRef]

8. Lazcka, O.; del Campo, F.J.; Muñoz, F.X. Pathogen detection: A perspective of traditional methods and biosensors. Biosens. Bioelectron. 2007, 22, 1205-1217. [CrossRef] [PubMed]

9. Tamplin, M.L. Integrating predictive models and sensors to manage food stability in supply chains. Food Microbiol. 2018, 75, 90-94. [CrossRef] [PubMed]

10. Eersels, K.; Lieberzeit, P.; Wagner, P. A Review on Synthetic Receptors for Bioparticle Detection Created by Surface-Imprinting Techniques-From Principles to Applications. ACS Sens. 2016, 1, 1171-1187. [CrossRef]

11. Iskierko, Z.; Sharma, P.S.; Bartold, K.; Pietrzyk-Le, A.; Noworyta, K.; Kutner, W. Molecularly imprinted polymers for separating and sensing of macromolecular compounds and microorganisms. Biotechnol. Adv. 2016, 34, 30-46. [CrossRef] [PubMed]

12. Alizadeh, N.; Salimi, A. Ultrasensitive Bioaffinity Electrochemical Sensors: Advances and New Perspectives. Electroanalysis 2018, 30, 2803-2840. [CrossRef]

13. Luong, J.H.; Male, K.B.; Glennon, J.D. Biosensor technology: Technology push versus market pull. Biotechnol. Adv. 2008, 26, 492-500. [CrossRef] [PubMed]

14. Haupt, K.; Mosbach, K. Molecularly imprinted polymers and their use in biomimetic sensors. Chem. Rev. 2000, 100, 2495-2504. [CrossRef] [PubMed]

15. Cieplak, M.; Kutner, W. Artificial Biosensors: How Can Molecular Imprinting Mimic Biorecognition? Trends Biotechnol. 2016, 34, 922-941. [CrossRef] [PubMed]

16. Mujahid, A.; Iqbal, N.; Afzal, A. Bioimprinting strategies: From soft lithography to biomimetic sensors and beyond. Biotechnol. Adv. 2013, 31, 1435-1447. [CrossRef] [PubMed]

17. Chen, L.; Wang, X.; Lu, W.; Wu, X.; Li, J. Molecular imprinting: Perspectives and applications. R. Soc. Chem. 2016, 45, $2137-2211$. [CrossRef] [PubMed]

18. Casadio, S.; Lowdon, J.W.; Betlem, K.; Ueta, J.T.; Foster, C.W.; Cleij, T.J.; van Grinsven, B.; Sutcliffe, O.B.; Banks, C.E.; Peeters, M. Development of a novel flexible polymer-based biosensor platform for the thermal detection of noradrenaline in aqueous solutions. Chem. Eng. J. 2017, 315, 459-468. [CrossRef]

19. Lowdon, J.W.; Eersels, K.; Rogosic, R.; Boonen, T.; Heidt, B.; Diliën, H.; van Grinsven, B.; Cleij, T.J. Surface grafted molecularly imprinted polymeric receptor layers for thermal detection of the New Psychoactive substance 2-methoxphenidine. Sens. Actuators A Phys. 2019, 295, 586-595. [CrossRef]

20. Cui, F.; Zhou, Z.; Zhou, H.S. Molecularly imprinted polymers and surface imprinted polymers based electrochemical biosensor for infectious diseases. Sensors 2020, 20, 996. [CrossRef] [PubMed]

21. Eersels, K.; van Grinsven, B.; Khorshid, M.; Somers, V.; Püttmann, C.; Stein, C.; Barth, S.; Diliën, H.; Bos, G.M.J.; Germeraad, W.T.V.; et al. Heat-transfer-method-based cell culture quality assay through cell detection by surface imprinted polymers. Langmuir 2015, 31, 2043-2050. [CrossRef]

22. Eersels, K.; van Grinsven, B.; Ethirajan, A.; Timmermans, S.; Jiménez Monroy, K.L.; Bogie, J.F.J.; Punniyakoti, S.; Vandenryt, T.; Hendriks, J.J.A.; Cleij, T.J.; et al. Selective Identification of Macrophages and Cancer Cells Based on Thermal Transport through Surface-Imprinted Polymer Layers. ACS Appl. Mater. Interfaces 2013, 5, 7258-7267. [CrossRef] [PubMed]

23. Schirhagl, R.; Qian, J.; Dickert, F.L. Immunosensing with artificial antibodies in organic solvents or complex matrices. Sens. Actuators B Chem. 2012, 173, 585-590. [CrossRef]

24. Phan, N.V.H.; Sussitz, H.F.; Ladenhauf, E.; Pum, D.; Lieberzeit, P.A. Combined Layer/Particle Approaches in Surface Molecular Imprinting of Proteins: Signal Enhancement and Competition. Sensors 2018, 18, 180. [CrossRef] [PubMed]

25. Zhao, X.; He, Y.; Wang, Y.; Wang, S.; Wang, J. Hollow molecularly imprinted polymer based quartz crystal microbalance sensor for rapid detection of methimazole in food samples. Food Chem. 2020, 309, 125787. [CrossRef]

26. Zhang, Z.; Guan, Y.; Li, M.; Zhao, A.; Ren, J.; Qu, X. Highly stable and reusable imprinted artificial antibody used for in situ detection and disinfection of pathogens. Chem. Sci. 2015, 6, 2822-2826. [CrossRef] [PubMed] 
27. Cai, W.; Li, H.-H.; Lu, Z.-X.; Collinson, M.M. Bacteria assisted protein imprinting in sol-gel derived films. Analyst 2018, 143, 555-563. [CrossRef] [PubMed]

28. van Grinsven, B.; Eersels, K.; Erkens-Hulshof, S.; Diliën, H.; Nurekeyeva, K.; Cornelis, P.; Klein, D.; Crijs, F.; Tuijthof, G.; Wagner, P.; et al. SIP-Based Thermal Detection Platform for the Direct Detection of Bacteria Obtained from a Contaminated Surface. Phys. Status Solidi Appl. Mater. Sci. 2018, 215, 1-5. [CrossRef]

29. Peeters, M.M.; van Grinsven, B.; Foster, C.W.; Cleij, T.J.; Banks, C.E. Introducing thermal wave transport analysis (TWTA): A thermal technique for dopamine detection by screen-printed electrodes functionalized with Molecularly Imprinted Polymer (MIP) particles. Molecules 2016, 21, 552. [CrossRef] [PubMed]

30. Steen Redeker, E.; Eersels, K.; Akkermans, O.; Royakkers, J.; Dyson, S.; Nurekeyeva, K.; Ferrando, B.; Cornelis, P.; Peeters, M.; Wagner, P.; et al. Biomimetic Bacterial Identification Platform Based on Thermal Wave Transport Analysis (TWTA) through Surface-Imprinted Polymers. ACS Infect. Dis. 2017, 3, 388-397. [CrossRef] [PubMed]

31. Ramanaviciene, A.; Ramanavicius, A. Molecularly imprinted polypyrrole-based synthetic receptor for direct detection of bovine leukemia virus glycoproteins. Biosens. Bioelectron. 2004, 20, 1076-1082. [CrossRef] [PubMed]

32. Farahi, R.H.; Passian, A.; Tetard, L.; Thundat, T. Critical issues in sensor science to aid food and water safety. ACS Nano. 2012, 6, 4548-4556. [CrossRef] [PubMed]

33. Golabi, M.; Kuralay, F.; Jager, E.W.; Beni, V.; Turner, A.P. Electrochemical bacterial detection using poly(3-aminophenylboronic acid)-based imprinted polymer. Biosens. Bioelectron. 2017, 93, 87-93. [CrossRef] [PubMed]

34. Zhang, L.; Wang, G.; Xiong, C.; Zheng, L.; He, J.; Ding, Y.; Lu, H.; Zhang, G.; Cho, K.; Qiu, L. Chirality detection of amino acid enantiomers by organic electrochemical transistor. Biosens. Bioelectron. 2018, 105, 121-128. [CrossRef] [PubMed]

35. King, T.; Cole, M.; Farber, J.M.; Eisenbrand, G.; Zabaras, D.; Fox, E.M.; Hill, J.P. Food safety for food security: Relationship between global megatrends and developments in food safety. Trends Food Sci. Technol. 2017, 68, 160-175. [CrossRef]

36. Cao, Y.; Feng, T.; Xu, J.; Xue, C. Recent advances of molecularly imprinted polymer-based sensors in the detection of food safety hazard factors. Biosens. Bioelectron. 2019, 141, 111447. [CrossRef] [PubMed]

37. Thévenot, D.R.; Toth, K.; Durst, R.A.; Wilson, G.S. Electrochemical biosensors: Recommended definitions and classification (Technical Report). Pure Appl. Chem. 1999, 71, 2333-2348. [CrossRef]

38. Pan, J.; Chen, W.; Ma, Y.; Pan, G. Molecularly imprinted polymers as receptor mimics for selective cell recognition. Chem. Soc. Rev. 2018, 47, 5574-5587. [CrossRef] [PubMed]

39. Hartley, J.H.; James, T.D.; Ward, C.M. Synthetic receptors. J. Chem. Soc. Perkin Trans. 1997, 4, 61. [CrossRef]

40. Srinivasan, N.; Kilburn, J.D. Combinatorial approaches to synthetic receptors. Curr. Opin. Chem. Biol. 2004. [CrossRef]

41. Mosbach, K. Molecular imprinting. Trends Biochem. Sci. 1994, 1, 9-14. [CrossRef]

42. Wulff, G. Molecular Imprinting in Cross-Linked Materials with the Aid of Molecular Templates-A Way towards Artificial Antibodies. Angew. Chem. Int. Ed. 1995, 34, 1812-1832. [CrossRef]

43. Hoshino, Y.; Shea, K.J. The evolution of plastic antibodies. J. Mater. Chem. 2011, 21, 3517-3521. [CrossRef]

44. Chen, W.; Tian, X.; He, W.; Li, J.; Feng, Y.; Pan, G. Emerging functional materials based on chemically designed molecular recognition. BMC Mater. 2020, 2, 1-22. [CrossRef]

45. Kryscio, D.R.; Peppas, N.A. Critical review and perspective of macromolecularly imprinted polymers. Acta Biomater. 2012, 8, 461-473. [CrossRef] [PubMed]

46. Resmini, M. Molecularly imprinted polymers as biomimetic catalysts. Anal. Bioanal. Chem. 2012, 402, 3021-3026. [CrossRef] [PubMed]

47. Ertürk, G.; Mattiasson, B. Molecular imprinting techniques used for the preparation of biosensors. Sensors 2017, 17, 288. [CrossRef] [PubMed]

48. Piletsky, S.A.; Alcock, S.; Turner, A.P. Molecular imprinting: At the edge of the third millennium. Trends Biotechnol. 2001, 19, 9-12. [CrossRef]

49. Crapnell, R.D.; Canfarotta, F.; Czulak, J.; Johnson, R.; Betlem, K.; Mecozzi, F.; Down, M.P.; Eersels, K.; van Grinsven, B.; Cleij, T.J.; et al. Thermal Detection of Cardiac Biomarkers Heart-Fatty Acid Binding Protein and ST2 Using a Molecularly Imprinted Nanoparticle-Based Multiplex Sensor Platform. ACS Sens. 2019, 4, 2838-2845. [CrossRef] [PubMed]

50. Heidt, B.; Rogosic, R.; Lowdon, J.W.; Desmond-Kennedy, M.; Jurgaityte, K.; Ferrer Orri, J.; Kronshorst, Y.; Mendez, S.; Rice, H.T.; Crijns, F.; et al. Biomimetic Bacterial Identification Platform Based on Thermal Transport Analysis Through Surface Imprinted Polymers: From Proof of Principle to Proof of Application. Phys. Status Solidi Appl. Mater. Sci. 2019, 216, 1800688. [CrossRef]

51. Pichon, V.; Chapuis-Hugon, F. Role of molecularly imprinted polymers for selective determination of environmental pollutants-A review. Anal. Chim. Acta. 2008, 622, 48-61. [CrossRef] [PubMed]

52. Huang, D.L.; Wang, R.Z.; Liu, Y.G.; Zeng, G.M.; Lai, C.; Xu, P.; Lu, B.A.; Xu, J.J.; Wang, C.; Huang, C. Application of molecularly imprinted polymers in wastewater treatment: A review. Environ. Sci. Pollut. Res. 2015, 22, 963-977. [CrossRef] [PubMed]

53. Kindschy, L.M.; Alocilja, E.C. A Review of Molecularly Imprinted Polymers for Biosensor Development for Food and Agricultural Applications. Trans. ASAE 2004, 47, 1375-1382. [CrossRef]

54. Lofgreen, J.E.; Ozin, G.A. Controlling morphology and porosity to improve performance of molecularly imprinted sol-gel silica. Chem. Soc. Rev. 2014, 43, 911-933. [CrossRef] [PubMed]

55. Sharma, P.S.; Dabrowski, M.; D'Souza, F.; Kutner, W. Surface development of molecularly imprinted polymer films to enhance sensing signals. TrAC Trends Anal. Chem. 2013, 51, 146-157. [CrossRef] 
56. Sellergren, B.; Allender, C.J. Molecularly imprinted polymers: A bridge to advanced drug delivery. Adv. Drug Deliv. Rev. 2005, 57, 1733-1741. [CrossRef] [PubMed]

57. Yan, H.; Kyung, H.R. Characteristic and synthetic approach of molecularly imprinted polymer. Int. J. Mol. Sci. 2006, 7, 155-178. [CrossRef]

58. Schneider, F.; Piletsky, S.; Piletska, E.; Guerreiro, A.; Ulbricht, M. Comparison of thin-layer and bulk MIPs synthesized by photoinitiated in situ crosslinking polymerization from the same reaction mixtures. J. Appl. Polym. Sci. 2005, 98, 362-372. [CrossRef]

59. Gao, B.; Fu, H.; Li, Y.; Du, R. Preparation of surface molecularly imprinted polymeric microspheres and their recognition property for basic protein lysozyme. J. Chromatogr. B Anal. Technol. Biomed. Life Sci. 2010, 21, 1731-1738. [CrossRef] [PubMed]

60. Li, X.; Pan, J.; Dai, J.; Dai, X.; Xu, L.; Wei, X.; Hang, H.; Li, C.; Liu, Y. Surface molecular imprinting onto magnetic yeast composites via atom transfer radical polymerization for selective recognition of cefalexin. Chem. Eng. J. 2012, 198-199, 503-511. [CrossRef]

61. Pardeshi, S.; Singh, S.K. Precipitation polymerization: A versatile tool for preparing molecularly imprinted polymer beads for chromatography applications. RSC Adv. 2016, 6, 23525-23536. [CrossRef]

62. Wang, J.; Cormack, P.A.G.; Sherrington, D.C.; Khoshdel, E. Monodisperse, Molecularly Imprinted Polymer Microspheres Prepared by Precipitation Polymerization for Affinity Separation Applications. Angew. Chem. Int. Ed. 2003, 115, 5494-5496. [CrossRef]

63. Pérez-Moral, N.; Mayes, A.G. Comparative study of imprinted polymer particles prepared by different polymerisation methods. Anal. Chim. Acta 2004, 504, 15-21. [CrossRef]

64. Kellens, E.; Bové, H.; Conradi, M.; D’Olieslaeger, L.; Wagner, P.; Landfester, K.; Junkers, T.; Ethirajan, A. Improved Molecular Imprinting Based on Colloidal Particles Made from Miniemulsion: A Case Study on Testosterone and Its Structural Analogues. Macromolecules 2016, 49, 2559-2567. [CrossRef]

65. Canfarotta, F.; Czulak, J.; Betlem, K.; Sachdeva, A.; Eersels, K.; van Grinsven, B.; Cleij, T.J.; Peeters, M. A novel thermal detection method based on molecularly imprinted nanoparticles as recognition elements. Nanoscale 2018, 10, 2081-2089. [CrossRef] [PubMed]

66. Adali-Kaya, Z.; Bui, B.T.S.; Falcimaigne-Cordin, A.; Haupt, K. Molecularly imprinted polymer nanomaterials and nanocomposites: Atom-transfer radical polymerization with acidic monomers. Angew. Chem. Int. Ed. 2015, 54, 5192-5195. [CrossRef]

67. Gonzato, C.; Pasetto, P.; Bedoui, F.; Mazeran, P.-E.; Haupt, K. On the effect of using RAFT and FRP for the bulk synthesis of acrylic and methacrylic molecularly imprinted polymers. Polym. Chem. 2014, 5, 1313-1322. [CrossRef]

68. Pan, G.; Zhang, Y.; Ma, Y.; Li, C.; Zhang, H. Efficient one-pot synthesis of water-compatible molecularly imprinted polymer microspheres by facile RAFT precipitation polymerization. Angew. Chem. Int. Ed. 2011, 50, 11731-11734. [CrossRef] [PubMed]

69. Crapnell, R.D.; Hudson, A.; Foster, C.W.; Eersels, K.; van Grinsven, B.; Cleij, T.J.; Banks, C.E.; Peeters, M. Recent advances in electrosynthesized molecularly imprinted polymer sensing platforms for bioanalyte detection. Sensors 2019, 19, 1204. [CrossRef] [PubMed]

70. Losito, I.; Palmisano, F.; Zambonin, P.G. o-phenylenediamine electropolymerization by cyclic voltammetry combined with electrospray ionization-ion trap mass spectrometry. Anal. Chem. 2003, 75, 4988-4995. [CrossRef]

71. Uang, Y.M.; Chou, T.C. Criteria for designing a polypyrrole glucose biosensor by galvanostatic electropolymerization. Electroanalysis 2002, 14, 1564-1570. [CrossRef]

72. Komaba, S.; Seyama, M.; Momma, T.; Osaka, T. Potentiometric biosensor for urea based on electropolymerized electroinactive polypyrrole. Electrochim. Acta 1997, 42, 383-388. [CrossRef]

73. Ye, L. Molecularly imprinted polymers with multi-functionality. Anal. Bioanal. Chem. 2016, 408, 1727-1733. [CrossRef] [PubMed]

74. Mahony, J.O.; Nolan, K.; Smyth, M.R.; Mizaikoff, B. Molecularly imprinted polymers-Potential and challenges in analytical chemistry. Anal. Chim. Acta 2005, 534, 31-39. [CrossRef]

75. Li, S.; Cao, S.; Whitcombe, M.J.; Piletsky, S.A. Size matters: Challenges in imprinting macromolecules. Prog. Polym. Sci. 2014, 39, 145-163. [CrossRef]

76. Chen, L.; Xu, S.; Li, J. Recent advances in molecular imprinting technology: Current status, challenges and highlighted applications. Chem. Soc. Rev. 2011, 40, 2922. [CrossRef] [PubMed]

77. Chen, S.; Chen, X.; Zhang, L.; Gao, J.; Ma, Q. Electrochemiluminescence Detection of Escherichia coli O157:H7 Based on a Novel Polydopamine Surface Imprinted Polymer Biosensor. ACS Appl. Mater. Interfaces 2017, 9, 5430-5436. [CrossRef] [PubMed]

78. Brown, M.E.; Puleo, D.A. Protein binding to peptide-imprinted porous silica scaffolds. Chem. Eng. J. 2008, 137, 97-101. [CrossRef] [PubMed]

79. Wang, Y.; Zhang, Z.; Jain, V.; Yi, J.; Mueller, S.; Sokolov, J.; Liu, Z.; Levon, K.; Rigas, B.; Rafailovich, M.H. Potentiometric sensors based on surface molecular imprinting: Detection of cancer biomarkers and viruses. Sens. Actuators B Chem. 2010, 146, 381-387. [CrossRef]

80. Tokonami, S.; Nakadoi, Y.; Takahashi, M.; Ikemizu, M.; Kadoma, T.; Saimatsu, K.; Dung, L.Q.; Shiigi, H.; Nagaoka, T. Label-free and selective bacteria detection using a film with transferred bacterial configuration. Anal. Chem. 2013, 85, 4925-4929. [CrossRef] [PubMed]

81. Deporter, S.M.; Lui, I.; McNaughton, B.R. Programmed cell adhesion and growth on cell-imprinted polyacrylamide hydrogels. Soft Matter 2012, 8, 10403-10408. [CrossRef]

82. Qi, P.; Wan, Y.; Zhang, D. Impedimetric biosensor based on cell-mediated bioimprinted films for bacterial detection. Biosens. Bioelectron. 2013, 39, 282-288. [CrossRef] 
83. Hayden, O.; Lieberzeit, P.A.; Blaas, D.; Dickert, F.L. Artificial antibodies for bioanalyte detection-Sensing viruses and proteins. Adv. Funct. Mater. 2006, 16, 1269-1278. [CrossRef]

84. Chunta, S.; Suedee, R.; Lieberzeit, P.A. High-density lipoprotein sensor based on molecularly imprinted polymer. Anal. Bioanal. Chem. 2018, 410, 875-883. [CrossRef]

85. Pluhar, B.; Ziener, U.; Mizaikoff, B. Surface imprinting of pepsin via miniemulsion polymerization. J. Mater. Chem. B 2013, 1, 5489-5495. [CrossRef] [PubMed]

86. Zeng, Z.; Hoshino, Y.; Rodriguez, A.; Yoo, H.; Shea, K.J. Synthetic polymer nanoparticles with antibody-like affinity for a hydrophilic peptide. ACS Nano 2010, 4, 199-204. [CrossRef]

87. Hu, Y.; Pan, J.; Zhang, K.; Lian, H.; Li, G. Novel applications of molecularly-imprinted polymers in sample preparation. TrAC Trends Anal. Chem. 2013, 43, 37-52. [CrossRef]

88. Alexander, C.; Davidson, L.; Hayes, W. Imprinted polymers: Artificial molecular recognition materials with applications in synthesis and catalysis. Tetrahedron 2003, 59, 2025-2057. [CrossRef]

89. Ramström, O.; Skudar, K.; Haines, J.; Patel, P.; Brüggemann, O. Food Analyses Using Molecularly Imprinted Polymers. J. Agric. Food Chem. 2001, 49, 2105-2114. [CrossRef] [PubMed]

90. Speltini, A.; Scalabrini, A.; Maraschi, F.; Sturini, M.; Profumo, A. Newest applications of molecularly imprinted polymers for extraction of contaminants from environmental and food matrices: A review. Anal. Chim. Acta 2017, 974, 1-26. [CrossRef]

91. Wang, P.; Sun, X.; Su, X.; Wang, T. Advancements of molecularly imprinted polymers in the food safety field. Analyst 2016, 141, 3540-3553. [CrossRef]

92. Song, X.; Xu, S.; Chen, L.; Wei, Y.; Xiong, H. Recent advances in molecularly imprinted polymers in food analysis. J. Appl. Polym. Sci. 2014, 131, 40766. [CrossRef]

93. Regal, P.; Díaz-Bao, M.; Barreiro, R.; Cepeda, A.; Fente, C. Application of molecularly imprinted polymers in food analysis: Clean-up and chromatographic improvements. Cent. Eur. J. Chem. 2012, 10, 766-784. [CrossRef]

94. Taylor, S.L. Chemical Intoxications. In Foodborne Diseases: Third Edition; Elsevier Inc.: Cambridge, MA, USA, 2017 ; pp. 447-458.

95. Zikankuba, V.L.; Mwanyika, G.; Ntwenya, J.E.; James, A.; Yildiz, F. Pesticide regulations and their malpractice implications on food and environment safety. Cogent Food Agric. 2019, 5, 1601544. [CrossRef]

96. Nunes, G.S.; Toscano, I.A.; Barceló, D. Analysis of pesticides in food and environmental samples by enzyme- linked immunosorbent assays. TrAC Trends Anal. Chem. 1998, 17, 79-87. [CrossRef]

97. Trasande, L.; Zoeller, R.T.; Hass, U.; Kortenkamp, A.; Grandjean, P.; Myers, J.P.; DiGangi, J.; Bellanger, M.; Hauser, R.; Legler, J.; et al. Estimating burden and disease costs of exposure to endocrine-disrupting chemicals in the European Union. J. Clin. Endocrinol. Metab. 2015, 100, 1245-1255. [CrossRef] [PubMed]

98. Sharma, D.; Nagpal, A.; Pakade, Y.B.; Katnoria, J.K. Analytical methods for estimation of organophosphorus pesticide residues in fruits and vegetables: A review. Talanta 2010, 82, 1077-1089. [CrossRef]

99. Aarestrup, F.M. Veterinary drug usage and antimicrobial resistance in bacteria of animal origin. Basic Clin. Pharm. Toxicol. 2005, 96, 271-281. [CrossRef] [PubMed]

100. Salleras, L.; Dominguez, A.; Mata, E.; Taberner, J.L.; Moro, I.; Salva, P. Epidemiologic study of an outbreak of clenbuterol poisoning in Catalonia, Spain. Public Health Rep. 1995, 110, 338-342. [PubMed]

101. Masiá, A.; Suarez-Varela, M.M.; Llopis-Gonzalez, A.; Picó, Y. Determination of pesticides and veterinary drug residues in food by liquid chromatography-mass spectrometry: A review. Anal. Chim.Acta 2016, 936, 40-61. [CrossRef] [PubMed]

102. Tadeo, J.L. Analysis of Pesticides in Food and Environmental Samples; CRC Press: Cleveland, OH, USA, 2008.

103. Seiber, J.N.; Kleinschmidt, L.A. Contributions of pesticide residue chemistry to improving food and environmental safety: Past and present accomplishments and future challenges. J. Agric. Food Chem. 2011, 14, 7536-7543. [CrossRef] [PubMed]

104. Abdel-Ghany, M.F.; Hussein, L.A.; El Azab, N.F. Novel potentiometric sensors for the determination of the dinotefuran insecticide residue levels in cucumber and soil samples. Talanta 2017, 164, 518-528. [CrossRef] [PubMed]

105. Motaharian, A.; Motaharian, F.; Abnous, K.; Hosseini, M.R.M.; Hassanzadeh-Khayyat, M. Molecularly imprinted polymer nanoparticles-based electrochemical sensor for determination of diazinon pesticide in well water and apple fruit samples. Anal. Bioanal. Chem. 2016, 408, 6769-6779. [CrossRef] [PubMed]

106. Li, Y.; Zhang, L.; Dang, Y.; Chen, Z.; Zhang, R.; Li, Y.; Ye, B.C. A robust electrochemical sensing of molecularly imprinted polymer prepared by using bifunctional monomer and its application in detection of cypermethrin. Biosens. Bioelectron. 2019, 127, 207-214. [CrossRef]

107. Aghoutane, Y.; Diouf, A.; Österlund, L.; Bouchikhi, B.; El Bari, N. Development of a molecularly imprinted polymer electrochemical sensor and its application for sensitive detection and determination of malathion in olive fruits and oils. Bioelectrochemistry 2020, 132, 107404. [CrossRef] [PubMed]

108. Abdalla, N.S.; Amr, A.E.-G.E.; El-Tantawy, A.S.M.; Al-Omar, M.A.; Kamel, A.H.; Khalifa, N.M. Tailor-made specific recognition of cyromazine pesticide integrated in a potentiometric strip cell for environmental and food analysis. Polymers 2019, 11, 1526. [CrossRef] [PubMed]

109. Khadem, M.; Faridbod, F.; Norouzi, P.; Foroushani, A.R.; Ganjali, M.R.; Shahtaheri, S.J. Biomimetic electrochemical sensor based on molecularly imprinted polymer for dicloran pesticide determination in biological and environmental samples. J. Iran. Chem. Soc. 2016, 13, 2077-2084. [CrossRef] 
110. Anirudhan, T.S.; Alexander, S. Design and fabrication of molecularly imprinted polymer-based potentiometric sensor from the surface modified multiwalled carbon nanotube for the determination of lindane ( $\gamma$-hexachlorocyclohexane), an organochlorine pesticide. Biosens. Bioelectron. 2015, 64, 586-593. [CrossRef] [PubMed]

111. Zhang, C.; Cui, H.; Cai, J.; Duan, Y.; Liu, Y. Development of Fluorescence Sensing Material Based on CdSe/ZnS Quantum Dots and Molecularly Imprinted Polymer for the Detection of Carbaryl in Rice and Chinese Cabbage. J. Agric. Food Chem. 2015, 63, 4966-4972. [CrossRef] [PubMed]

112. Fang, G.; Yang, Y.; Zhu, H.; Qi, Y.; Liu, J.; Liu, H.; Wang, S. Development and application of molecularly imprinted quartz crystal microbalance sensor for rapid detection of metolcarb in foods. Sens. Actuators B Chem. 2017, 251, 720-728. [CrossRef]

113. Gholivand, M.B.; Torkashvand, M.; Malekzadeh, G. Fabrication of an electrochemical sensor based on computationally designed molecularly imprinted polymers for determination of cyanazine in food samples. Anal. Chim. Acta 2012, 713, 36-44. [CrossRef]

114. Xu, L.; Li, J.; Zhang, J.; Sun, J.; Gan, T.; Liu, Y.-M. A disposable molecularly imprinted electrochemical sensor for the ultra-trace detection of the organophosphorus insecticide phosalone employing monodisperse Pt-doped UiO-66 for signal amplification. Analyst 2020, 145, 3245-3256. [CrossRef] [PubMed]

115. Dayal, H.; Ng, W.Y.; Lin, X.H.; Li, S.F.Y. Development of a hydrophilic molecularly imprinted polymer for the detection of hydrophilic targets using quartz crystal microbalance. Sens. Actuators B Chem. 2019, 300, 127044. [CrossRef]

116. CG, A.M.; Akshaya, K.B.; Rison, S.; Varghese, A.; George, L. Molecularly imprinted PEDOT on carbon fiber paper electrode for the electrochemical determination of 2,4-dichlorophenol. Synth. Met. 2020, 261, 116309.

117. Feng, S.; Li, Y.; Zhang, R.; Li, Y. A novel electrochemical sensor based on molecularly imprinted polymer modified hollow N, S-Mo2C/C spheres for highly sensitive and selective carbendazim determination. Biosens. Bioelectron. 2019, $142,111491$. [CrossRef] [PubMed]

118. Li, H.; Wang, Z.; Wu, B.; Liu, X.; Xue, Z.; Lu, X. Rapid and sensitive detection of methyl-parathion pesticide with an electropolymerized, molecularly imprinted polymer capacitive sensor. Electrochim. Acta 2012. [CrossRef]

119. Chen, D.; Deng, J.; Liang, J.; Xie, J.; Hu, C.; Huang, K. A core-shell molecularly imprinted polymer grafted onto a magnetic glassy carbon electrode as a selective sensor for the determination of metronidazole. Sens. Actuators B Chem. 2013, 183, 594-600. [CrossRef]

120. Wei, X.; Zhang, Z.; Zhang, L.; Xu, X. Synthesis of molecularly imprinted polymers/NiCo2O4 nanoneedle arrays on 3D graphene electrode for determination of sulfadimidine residue in food. J. Mater. Sci. 2019, 54, 2066-2078. [CrossRef]

121. Zhang, T.; Liu, J.; Wang, J.-P. Preparation of a molecularly imprinted polymer based chemiluminescence sensor for the determination of amantadine and rimantadine in meat. Anal. Methods 2018, 10, 5025-5031. [CrossRef]

122. Alizadeh, T.; Ganjali, M.R.; Zare, M.; Norouzi, P. Selective determination of chloramphenicol at trace level in milk samples by the electrode modified with molecularly imprinted polymer. Food Chem. 2012, 130, 1108-1114. [CrossRef]

123. Munawar, A.; Tahir, M.A.; Shaheen, A.; Lieberzeit, P.A.; Khan, W.S.; Bajwa, S.Z. Investigating nanohybrid material based on 3D CNTs@Cu nanoparticle composite and imprinted polymer for highly selective detection of chloramphenicol. J. Hazard. Mater. 2018, 15, 96-106. [CrossRef] [PubMed]

124. Andrea, P.; Miroslav, S.; Silvia, S.; Stanislav, M. A solid binding matrix/molecularly imprinted polymer-based sensor system for the determination of clenbuterol in bovine liver using differential-pulse voltammetry. Sens. Actuators B Chem. 2001, 76, 286-294. [CrossRef]

125. Li, Z.B.; Liu, J.; Liu, J.X.; Wang, Z.H.; Wang, J.P. Determination of sulfonamides in meat with dummy-template molecularly imprinted polymer-based chemiluminescence sensor. Anal. Bioanal. Chem. 2019, 411, 3179-3189. [CrossRef] [PubMed]

126. Long, F.; Zhang, Z.; Yang, Z.; Zeng, J.; Jiang, Y. Imprinted electrochemical sensor based on magnetic multi-walled carbon nanotube for sensitive determination of kanamycin. J. Electroanal. Chem. 2015, 755, 7-14. [CrossRef]

127. Li, L.; Lin, Z.; Huang, Z.; Peng, A. Rapid detection of sulfaguanidine in fish by using a photonic crystal molecularly imprinted polymer. Food Chem. 2019, 281, 57-62. [CrossRef] [PubMed]

128. Tang, Y.; Liu, H.; Gao, J.; Liu, X.; Gao, X.; Lu, X.; Fang, G.; Wang, J.; Li, J. Upconversion particle@Fe3O4@molecularly imprinted polymer with controllable shell thickness as high-performance fluorescent probe for sensing quinolones. Talanta 2018, 181, 95-103. [CrossRef] [PubMed]

129. Cai, Y.; He, X.; Cui, P.L.; Liu, J.; Zhao, B.L.; Jia, B.J.; Zhang, T.; Wang, J.P.; Yuan, W.Z. Preparation of a chemiluminescence sensor for multi-detection of benzimidazoles in meat based on molecularly imprinted polymer. Food Chem. 2019, 280, 103-109. [CrossRef] [PubMed]

130. BEbarvia, B.S.; Ubando, I.E.; Sevilla, F.B. Biomimetic piezoelectric quartz crystal sensor with chloramphenicol-imprinted polymer sensing layer. Talanta 2015, 144, 1260-1265. [CrossRef]

131. Yola, M.L.; Atar, N.; Erdem, A. Oxytocin imprinted polymer based surface plasmon resonance sensor and its application to milk sample. Sens. Actuators B Chem. 2015, 221, 842-848. [CrossRef]

132. Han, Q.; Shen, X.; Zhu, W.; Zhu, C.; Zhou, X.; Jiang, H. Magnetic sensing film based on Fe3O4@Au-GSH molecularly imprinted polymers for the electrochemical detection of estradiol. Biosens. Bioelectron. 2016, 79, 180-186. [CrossRef]

133. Zhao, W.-R.; Kang, T.-F.; Lu, L.-P.; Cheng, S.-Y. Electrochemical magnetic imprinted sensor based on MWCNTs@CS/CTABr surfactant composites for sensitive sensing of diethylstilbestrol. J. Electroanal. Chem. 2018, 818, 181-190. [CrossRef]

134. Zhang, Z.; Xuc, J.; Wen, Y.; Zhang, J.; Ding, W. The electro-synthesized imprinted PEDOT film as a simple voltammetric sensor for highly sensitive and selective detection of vitamin K3 in poultry drug samples. Synth. Met. 2017, 230, 79-88. [CrossRef] 
135. Gupta, V.K.; Yola, M.L.; Özaltin, N.; Atar, N.; Üstündağ, Z.; Uzun, L. Molecular imprinted polypyrrole modified glassy carbon electrode for the determination of tobramycin. Electrochim. Acta 2013, 112, 37-43. [CrossRef]

136. Radi, A.E.; El-Naggar, A.E.; Nassef, H.M. Molecularly imprinted polymer based electrochemical sensor for the determination of the anthelmintic drug oxfendazole. J. Electroanal. Chem. 2014, 729, 135-141. [CrossRef]

137. Liu, B.; Tang, D.; Zhang, B.; Que, X.; Yang, H.; Chen, G. Au(III)-promoted magnetic molecularly imprinted polymer nanospheres for electrochemical determination of streptomycin residues in food. Biosens. Bioelectron. 2013, 41, 551-556. [CrossRef] [PubMed]

138. Ashley, J.; Shokor, Y.; D'Aurelio, R.; Trinh, L.; Rodgers, T.L.; Temblay, J.; Pleasants, M.; Tothill, I.E. Synthesis of Molecularly Imprinted Polymer Nanoparticles for $\alpha$-Casein Detection Using Surface Plasmon Resonance as a Milk Allergen Sensor. ACS Sens. 2018, 3, 418-424. [CrossRef] [PubMed]

139. He, T.; Wang, G.N.; Liu, J.X.; Zhao, W.L.; Huang, J.J.; Xu, M.X.; Wang, J.P.; Liu, J. Dummy molecularly imprinted polymer based microplate chemiluminescence sensor for one-step detection of Sudan dyes in egg. Food Chem. 2019, 288, 347-353. [CrossRef] [PubMed]

140. Zhao, C.; Zhao, T.; Liu, X.; Zhang, H. A novel molecularly imprinted polymer for simultaneous extraction and determination of sudan dyes by on-line solid phase extraction and high performance liquid chromatography. J. Chromatogr. A 2010, 1217, 6995-7002. [CrossRef]

141. Jiang, S.; Peng, Y.; Ning, B.; Bai, J.; Liu, Y.; Zhang, N.; Gao, Z. Surface plasmon resonance sensor based on molecularly imprinted polymer film for detection of histamine. Sens. Actuators B Chem. 2015, 221, 15-21. [CrossRef]

142. Dai, J.; Zhang, Y.; Pan, M.; Kong, L.; Wang, S. Development and application of quartz crystal microbalance sensor based on novel molecularly imprinted sol-gel polymer for rapid detection of histamine in foods. J. Agric. Food Chem. 2014, 62, 5269-5274. [CrossRef] [PubMed]

143. Yin, W.; Wu, L.; Ding, F.; Li, Q.; Lu, Z.; Han, H. Surface-imprinted SiO2@Ag nanoparticles for the selective detection of BPA using surface enhanced Raman scattering. Sens. Actuators B Chem. 2018, 258, 566-573. [CrossRef]

144. Liu, X.; Mao, L.G.; Wang, Y.L.; Shi, X.B.; Liu, Y.; Yang, Y.; He, Z. Electrochemical Sensor based on Imprinted Sol-Gel Polymer on Au NPs-MWCNTs-CS Modified Electrode for the Determination of Acrylamide. Food Anal. Methods 2016, 9, 114-121. [CrossRef]

145. Ji, J.; Sun, X.; Tian, X.; Li, Z.; Zhang, Y. Synthesis of Acrylamide Molecularly Imprinted Polymers Immobilized on Graphite Oxide through Surface-Initiated Atom Transfer Radical Polymerization. Anal. Lett. 2013, 46, 969-981. [CrossRef]

146. Khlifi, A.; Gam-Derouich, S.; Jouini, M.; Kalfat, R.; Chehimi, M.M. Melamine-imprinted polymer grafts through surface photopolymerization initiated by aryl layers from diazonium salts. Food Control 2013, 31, 379-386. [CrossRef]

147. Liu, Y.T.; Deng, J.; Xiao, X.L.; Ding, L.; Yuan, Y.L.; Li, H.; Li, X.T.; Yan, X.N.; Wang, L.L. Electrochemical sensor based on a poly(para-aminobenzoic acid) film modified glassy carbon electrode for the determination of melamine in milk. Electrochim. Acta 2011, 56, 4595-4602. [CrossRef]

148. Shamsipur, M.; Moradi, N.; Pashabadi, A. Coupled electrochemical-chemical procedure used in construction of molecularly imprinted polymer-based electrode: A highly sensitive impedimetric melamine sensor. J. Solid State Electrochem. 2018, 22, 169-180. [CrossRef]

149. Havelaar, A.H.; Kirk, M.D.; Torgerson, P.R.; Gibb, H.J.; Hald, T.; Lake, R.J.; Praet, N.; Bellinger, D.C.; de Silva, N.R.; Gargouri, N.; et al. World Health Organization Global Estimates and Regional Comparisons of the Burden of Foodborne Disease in 2010. PLoS Med. 2015, 12, e1001923. [CrossRef] [PubMed]

150. Rocourt, J.; Moy, G.; Vierk, K.; Schlundt, J. The present state of foodborne disease in OECD countries WHO Library Cataloguingin-Publication Data. WHO Libr. Cat. Publ. 2003, 1, 1-39.

151. Musher, D.M.; Musher, B.L. Contagious acute gastrointestinal infections. N. Eng. J. Med. 2004, 351, 2417-2427. [CrossRef] [PubMed]

152. Bintsis, T. Foodborne pathogens. AIMS Microbiol. 2017, 3, 529-536. [CrossRef]

153. Authority, European Food Safety. The European Union summary report on trends and sources of zoonoses, zoonotic agents and food-borne outbreaks in 2017. EFSA J. 2017, 15, 5077.

154. Rahn, K.; De Grandis, S.A.; Clarke, R.C.; McEwen, S.A.; Galán, J.E.; Ginocchio, C.; Curtiss III, R.; Gyles, C.L. Amplification of an invA gene sequence of Salmonella typhimurium by polymerase chain reaction as a specific method of detection of Salmonella. Mol. Cell. Probes 1992, 6, 271-279. [CrossRef]

155. Pollard, D.R.; Johnson, W.M.; Lior, H.; Tyler, S.D.; Rozee, K.R. Rapid and specific detection of verotoxin genes in Escherichia coli by the polymerase chain reaction. J. Clin. Microbiol. 1990, 28, 540-545. [CrossRef] [PubMed]

156. Gracias, K.S.; McKillip, J.L. A review of conventional detection and enumeration methods for pathogenic bacteria in food. Can. J. Microbiol. 2004, 50, 883-890. [CrossRef]

157. Maciorowski, K.G.; Herrera, P.; Jones, F.T.; Pillai, S.D.; Ricke, S.C. Cultural and immunological detection methods for Salmonella spp. in animal feeds-A review. Vet. Res. Commun. 2006, 30, 127-137. [CrossRef]

158. Adzitey, F.; Huda, N.; Ali, G.R.R. Molecular techniques for detecting and typing of bacteria, advantages and application to foodborne pathogens isolated from ducks. 3 Biotech 2013, 3, 97-107. [CrossRef]

159. Brugger, S.D.; Baumberger, C.; Jost, M.; Jenni, W.; Brugger, U.; Mühlemann, K. Automated counting of bacterial colony forming units on agar plates. PLoS ONE 2012, 7, e33695. [CrossRef] [PubMed]

160. Velusamy, V.; Arshak, K.; Korostynska, O.; Oliwa, K.; Adley, C. An overview of foodborne pathogen detection: In the perspective of biosensors. Biotechnol. Adv. 2010, 28, 232-254. [CrossRef] 
161. From, C.; Hormazabal, V.; Granum, P.E. Food poisoning associated with pumilacidin-producing Bacillus pumilus in rice. Int. J. Food Microbiol. 2007, 115, 319-324. [CrossRef] [PubMed]

162. Sweeney, M.J.; White, S.; Dobson, A.D.W. Mycotoxins in agriculture and food safety. Irish J. Agric. Food Res. 2000, 39, $235-244$.

163. Schmitt, I.; Partida-Martinez, L.P.; Winkler, R.; Voigt, K.; Einax, E.; Dölz, F.; Telle, S.; Wöstemeyer, J.; Hertweck, C. Evolution of host resistance in a toxin-producing bacterial-funga. ISME J. 2008, 2, 632-641. [CrossRef] [PubMed]

164. Wu, F.; Groopman, J.D.; Pestka, J.J. Public Health Impacts of Foodborne Mycotoxins. Annu. Rev. Food Sci. Technol. 2014, 5, 351-372. [CrossRef]

165. Argudín, M.Á.; Mendoza, M.C.; Rodicio, M.D.R.R. Food Poisoning and Staphylococcus aureus Enterotoxins. Toxins 2010, 2, 1751-1773. [CrossRef] [PubMed]

166. Weiss, R.; Freudenschuss, M.; Krska, R.; Mizaikoff, B. Improving methods of analysis for mycotoxins: Molecularly imprinted polymers for deoxynivalenol and zearalenone. Food Addit. Contam. 2003, 20, 386-395. [CrossRef] [PubMed]

167. Koopmans, M.; Duizer, E. Foodborne viruses: An emerging problem. Int. J. Food Microbiol. 2004, 90, 23-41. [CrossRef]

168. Cliver, D.O. Virus transmission via food. World Health Stat. Q. 1997, 50, 90-101. [PubMed]

169. RAtmar, L.; Estes, M.K. Diagnosis of noncultivatable gastroenteritis viruses, the human caliciviruses. Clin. Microbiol. Rev. 2001, 14, 15-37. [CrossRef] [PubMed]

170. Tsarev, S.A.; Tsareva, T.S.; Emerson, S.U.; Kapikian, A.Z.; Ticehurst, J.; London, W.; Purcell, R.H. ELISA for Antibody to Hepatitis E Virus (HEV) Based on Complete Open-Reading Frame-2 Protein Expressed in Insect Cells: Identification of HEV Infection in Primates. J. Infect. Dis. 1993, 168, 369-378. [CrossRef] [PubMed]

171. Usuda, S.; Okamoto, H.; Iwanari, H.; Baba, K.; Tsuda, F.; Miyakawa, Y.; Mayumi, M. Serological detection of hepatitis B virus genotypes by ELISA with monoclonal antibodies to type-specific epitopes in the preS2-region product. J. Virol. Methods 1999, 80, 97-112. [CrossRef]

172. Payungporn, S.; Chutinimitkul, S.; Chaising, A.; Damrongwantanapokin, S.; Buranathai, C.; Amonsin, A.; Theamboonlers, A.; Poovorawan, Y. Single step multiplex real-time RT-PCR for H5N1 influenza A virus detection. J. Virol. Methods 2006, 131, $143-147$. [CrossRef]

173. Spackman, E.; Senne, D.A.; Myers, T.J.; Bulaga, L.L.; Garber, L.P.; Perdue, M.L.; Lohman, K.; Daum, L.T.; Suarez, D.L. Development of a real-time reverse transcriptase PCR assay for type A influenza virus and the avian H5 and H7 hemagglutinin subtypes. J. Clin. Microbiol. 2002, 40, 3256-3260. [CrossRef]

174. De Smet, D.; Dubruel, P.; Van Peteghem, C.; Schacht, E.; De Saeger, S. Molecularly imprinted solid-phase extraction of fumonisin B analogues in bell pepper, rice and corn flakes. Food Addit. Contam. Part A 2009, 26, 874-884. [CrossRef] [PubMed]

175. Appell, M.; Mueller, A. Mycotoxin analysis using imprinted materials technology: Recent developments. J. AOAC Int. 2016, 99, 861-864. [CrossRef] [PubMed]

176. Navarro-Villoslada, F.; Urraca, J.L.; Moreno-Bondi, M.C.; Orellana, G.; Orellana, G. Zearalenone sensing with molecularly imprinted polymers and tailored fluorescent probes. Sens. Actuators B Chem. 2007, 121, 67-73. [CrossRef]

177. Sergeyeva, T.; Yarynka, D.; Piletska, E.; Lynnik, R.; Zaporozhets, O.; Brovko, O.; Piletsky, S.; El'skaya, A. Fluorescent sensor systems based on nanostructured polymeric membranes for selective recognition of Aflatoxin B1. Talanta 2017, 175, 101-107. [CrossRef]

178. van Grinsven, B.; Eersels, K.; Akkermans, O.; Ellermann, S.; Kordek, A.; Peeters, M.; Deschaume, O.; Bartic, C.; Diliën, H.; Steen Rederker, E.; et al. Label-Free Detection of Escherichia coli Based on Thermal Transport through Surface Imprinted Polymers. ACS Sens. 2016, 1, 1140-1147. [CrossRef]

179. Shan, X.; Yamauchi, T.; Yamamoto, Y.; Shiigi, H.; Nagaoka, T. A rapid and specific bacterial detection method based on cell-imprinted microplates. Analyst 2018, 143, 1568-1574. [CrossRef] [PubMed]

180. Betlem, K.; Hoksbergen, S.; Mansouri, N.; Down, M.; Losada-Pérez, P.; Eersels, K.; van Grinsven, B.; Cleij, T.J.; Kelly, P.; Sawtell, D.; et al. Real-time analysis of microbial growth by means of the Heat-Transfer Method (HTM) using Saccharomyces cerevisiae as model organism. Phys. Med. 2018, 6, 1-8. [CrossRef]

181. Blanco-López, M.; Lobo-Castañón, M.; Miranda-Ordieres, A.; Tuñón-Blanco, P. Electrochemical sensors based on molecularly imprinted polymers. TrAC Trends Anal. Chem. 2004, 23, 36-48. [CrossRef]

182. Li, H.; Zhao, L.; Xu, Y.; Zhou, T.; Liu, H.; Huang, N.; Ding, J.; Li, Y.; Ding, L. Single-hole hollow molecularly imprinted polymer embedded carbon dot for fast detection of tetracycline in honey. Talanta 2018, i185, 542-549. [CrossRef]

183. Uzun, L.; Turner, A.P.F. Molecularly-imprinted polymer sensors: Realising their potential. Biosens. Bioelectron. 2016, 76, 131-144. [CrossRef] [PubMed]

184. Mitruka, B.M.; Bonner, M.J. Methods of Detection and Identification of Bacteria; CRC Press: Cleveland, OH, USA, 2017.

185. Levin, P.A.; Angert, E.R. Small but mighty: Cell size and bacteria. Cold Spring Harb. Perspect. Biol. 2015, 7, a019216. [CrossRef] [PubMed]

186. Sergeyeva, T.; Yarynka, D.; Piletska, E.; Linnik, R.; Zaporozhets, O.; Brovko, O.; Piletsky, S.; El'skaya, A. Development of a smartphone-based biomimetic sensor for aflatoxin B1 detection using molecularly imprinted polymer membranes. Talanta 2019, 201, 204-210. [CrossRef] [PubMed]

187. Turan, E.; Şahin, F. Molecularly imprinted biocompatible magnetic nanoparticles for specific recognition of Ochratoxin A. Sens. Actuators B Chem. 2016, 227, 668-676. [CrossRef] 
188. Liu, N.; Li, X.; Ma, X.; Ou, G.; Gao, Z. Rapid and multiple detections of staphylococcal enterotoxins by two-dimensional molecularly imprinted film-coated QCM sensor. Sens. Actuators B Chem. 2014, 191, 326-331. [CrossRef]

189. Liu, N.; Zhao, Z.; Chen, Y.; Gao, Z. Rapid Detection of Staphylococcal Enterotoxin B by Two-Dimensional Molecularly Imprinted Film-Coated Quartz Crystal Microbalance. Anal. Lett. 2012, 45, 283-295. [CrossRef]

190. Fang, G.; Wang, H.; Yang, Y.; Liu, G.; Wang, S. Development and application of a quartz crystal microbalance sensor based on molecularly imprinted sol-gel polymer for rapid detection of patulin in foods. Sens. Actuators B Chem. 2016, 237, 239-246. [CrossRef]

191. Guo, W.; Pi, F.; Zhang, H.; Sun, J.; Zhang, Y.; Sun, X. A novel molecularly imprinted electrochemical sensor modified with carbon dots, chitosan, gold nanoparticles for the determination of patulin. Biosens. Bioelectron. 2017, 98, 299-304. [CrossRef] [PubMed]

192. Zhang, W.; Han, Y.; Chen, X.; Luo, X.; Wang, J.; Yue, T.; Li, Z. Surface molecularly imprinted polymer capped Mn-doped ZnS quantum dots as a phosphorescent nanosensor for detecting patulin in apple juice. Food Chem. 2017, 232, 145-154. [CrossRef]

193. Pacheco, J.G.; Castro, M.; Machado, S.; Barroso, M.F.; Nouws, H.P.A.; Delerue-Matos, C. Molecularly imprinted electrochemical sensor for ochratoxin A detection in food samples. Sens. Actuators B Chem. 2015, 215, 107-112. [CrossRef]

194. Choi, S.W.; Chang, H.J.; Lee, N.; Kim, J.H.; Chun, H.S. Detection of mycoestrogen zearalenone by a molecularly imprinted polypyrrole-based surface plasmon resonance (SPR)sensor. J. Agric. Food Chem. 2009, 57, 1113-1118. [CrossRef] [PubMed]

195. Fang, G.; Fan, C.; Liu, H.; Pan, M.; Zhu, H.; Wang, S. A novel molecularly imprinted polymer on CdSe/ZnS quantum dots for highly selective optosensing of mycotoxin zearalenone in cereal samples. RSC Adv. 2014, 4, 2764-2771. [CrossRef]

196. Radi, A.E.; Eissa, A.; Wahdan, T. Impedimetric sensor for deoxynivalenol based on electropolymerised molecularly imprinted polymer on the surface of screen-printed gold electrode. Int. J. Environ. Anal. Chem. 2019, 00, 1-12. [CrossRef]

197. Zhao, X.; Cui, Y.; Wang, J. Preparation of fluorescent molecularly imprinted polymers via pickering emulsion interfaces and the application for visual sensing analysis of Listeria Monocytogenes. Polymers 2019, 11, 984. [CrossRef] [PubMed]

198. Cornelis, P.; Givanoudi, S.; Yongabi, D.; Iken, H.; Duwé, S.; Deschaume, O.; Robbens, J.; Dedecker, P.; Bartic, C.; Wübbenhorst, M.; et al. Sensitive and specific detection of E. coli using biomimetic receptors in combination with a modified heat-transfer method. Biosens. Bioelectron. 2019, 136, 97-105. [CrossRef]

199. Perçin, I.; Idil, N.; Bakhshpour, M.; Yılmaz, E.; Mattiasson, B.; Denizli, A. Microcontact imprinted plasmonic nanosensors: Powerful tools in the detection of salmonella paratyphi. Sensors 2017, 17, 1375. [CrossRef] [PubMed]

200. Y1lmaz, E.; Majidi, D.; Ozgur, E.; Denizli, A. Whole cell imprinting based Escherichia coli sensors: A study for SPR and QCM. Sens. Actuators B Chem. 2015, 209, 714-721. [CrossRef]

201. Yang, B.; Gong, H.; Chen, C.; Chen, X.; Cai, C. A virus resonance light scattering sensor based on mussel-inspired molecularly imprinted polymers for high sensitive and high selective detection of Hepatitis A Virus. Biosens. Bioelectron. 2017, 87, 679-685. [CrossRef] [PubMed]

202. Bhalla, N.; Jolly, P.; Formisano, N.; Estrela, P. Introduction to biosensors. Essays Biochem. 2016, 60, 1-8.

203. Duffy, G.F.; Moore, E.J. Electrochemical Immunosensors for Food Analysis: A Review of Recent Developments. Anal. Lett. 2017, 50, 1-32. [CrossRef]

204. Rotariu, L.; Lagarde, F.; Jaffrezic-Renault, N.; Bala, C. Electrochemical biosensors for fast detection of food contaminants-trends and perspective. TrAC Trends Anal. Chem. 2016, 79, 80-87. [CrossRef]

205. Kumar, H.; Neelam, R. Enzyme-based electrochemical biosensors for food safety: A review. Nanobiosens. Dis. Diagn. 2016, 5, 29-39. [CrossRef]

206. Mitra, S.; Cumming, D.R.S. CMOS Circuits for Biological Sensing and Processing; Springer: Berlin, Germany, 2017.

207. Alvarez-Lorenzo, C.; Concheiro, A. Molecularly Imprinted Polymers as Components of Drug Delivery Systems. In Handbook of Molecularly Imprinted Polymers; Smithers Rapra: Shawbury, UK, 2013.

208. Bougrini, M.; Florea, A.; Cristea, C.; Sandulescu, R.; Vocanson, F.; Errachid, A.; Bouchikhi, E.; El Bari, N.; Jaffrezic-Renault, N. Development of a novel sensitive molecularly imprinted polymer sensor based on electropolymerization of a microporous-metalorganic framework for tetracycline detection in honey. Food Control 2016, 59, 424-429. [CrossRef]

209. Idil, N.; Hedström, M.; Denizli, A.; Mattiasson, B. Whole cell based microcontact imprinted capacitive biosensor for the detection of Escherichia coli. Biosens. Bioelectron. 2017, 87, 807-815. [CrossRef] [PubMed]

210. Regasa, M.B.; Soreta, T.R.; Femi, O.E.; Ramamurthy, P.C. Development of Molecularly Imprinted Conducting Polymer Composite Film-Based Electrochemical Sensor for Melamine Detection in Infant Formula. ACS Omega 2020, 5, 4090-4099. [CrossRef] [PubMed]

211. Rao, H.; Chen, M.; Ge, H.; Lu, Z.; Liu, X.; Zou, P.; Wang, X.; He, H.; Zeng, X.; Wang, Y. A novel electrochemical sensor based on Au@PANI composites film modified glassy carbon electrode binding molecular imprinting technique for the determination of melamine. Biosens. Bioelectron. 2017, 87, 1029-1035. [CrossRef] [PubMed]

212. Bai, J.; Zhang, X.; Peng, Y.; Hong, X.; Liu, Y.; Jiang, S.; Ning, B.; Gao, Z. Ultrasensitive sensing of diethylstilbestrol based on AuNPs/MWCNTs-CS composites coupling with sol-gel molecularly imprinted polymer as a recognition element of an electrochemical sensor. Sens. Actuators B Chem. 2017, 238, 420-426. [CrossRef]

213. Mao, L.; Ji, K.; Yao, L.; Xue, X.; Wen, W.; Zhang, X.; Wang, S. Molecularly imprinted photoelectrochemical sensor for fumonisin B 1 based on GO-CdS heterojunction. Biosens. Bioelectron. 2019, 127, 57-63. [CrossRef] [PubMed]

214. Zhang, W.; Xiong, H.; Chen, M.; Zhang, X.; Wang, S. Surface-enhanced molecularly imprinted electrochemiluminescence sensor based on Ru@SiO2 for ultrasensitive detection of fumonisin B1. Biosens. Bioelectron. 2017, 96, 55-61. [CrossRef] [PubMed] 
215. Ahmad, O.S.; Bedwell, T.S.; Esen, C.; Garcia-Cruz, A.; Piletsky, S.A. Molecularly Imprinted Polymers in Electrochemical and Optical Sensors. Trends Biotechnol. 2019, 37, 294-309. [CrossRef] [PubMed]

216. Wang, H.; Yi, J.; Velado, D.; Yu, Y.; Zhou, S. Immobilization of Carbon Dots in Molecularly Imprinted Microgels for Optical Sensing of Glucose at Physiological pH. ACS Appl. Mater. Interfaces 2015, 7, 15735-15745. [CrossRef] [PubMed]

217. Liu, X.; Liu, Q.; Kong, F.; Qiao, X.; Xu, Z. Molecularly imprinted fluorescent probe based on hydrophobic CdSe/ZnS quantum dots for the detection of methamidophos in fruit and vegetables. Adv. Polym. Technol. 2018, 37, 1790-1796. [CrossRef]

218. Liedberg, B.; Nylander, C.; Lundstrom, I. Surface Plasmon Resonance for gas detection and biosensing. Sens. Actuators 1983, 4, 299-304. [CrossRef]

219. Leonard, P.; Hearty, S.; Brennan, J.; Dunne, L.; Quinn, J.; Chakraborty, T.; O’Kennedy, R. Advances in biosensors for detection of pathogens in food and water. Adv. Biosens. Detect. Pathog. Food Water 2003, 32, 3-13. [CrossRef]

220. Zhang, L.; Zhu, C.; Chen, C.; Zhu, S.; Zhou, J.; Wang, M.; Shang, P. Determination of kanamycin using a molecularly imprinted SPR sensor. Food Chem. 2018, 266, 170-174. [CrossRef] [PubMed]

221. Law, J.W.-F.; Ab Mutalib, N.-S.; Chan, K.-G.; Lee, L.-H. Rapid methods for the detection of foodborne bacterial pathogens: Principles, applications, advantages and limitations. Front. Microbiol. 2014, 5, 1-19. [CrossRef]

222. Yola, M.L.; Uzun, L.; Özaltin, N.; Denizli, A. Development of molecular imprinted nanosensor for determination of tobramycin in pharmaceuticals and foods. Talanta 2014, 120, 318-324. [CrossRef]

223. Van Grinsven, B.; Betlem, K.; Cleij, T.; Banks, C.; Peeters, M. Evaluating the potential of thermal read-out techniques combined with molecularly imprinted polymers for the sensing of low-weight organic molecules. J. Mol. Recognit. 2016, 30, 1-12. [CrossRef] [PubMed]

224. Radke, S.; Alocilja, E. Market analysis of biosensors for food safety. Biosens. Bioelectron. 2003, 18, 841-846.

225. Choi, J.R.; Yong, K.W.; Choi, J.Y.; Cowie, A.C. Emerging point-of-care technologies for food safety analysis. Sensors $2019,19,817$. [CrossRef] [PubMed]

226. Liu, W.; Guo, Y.; Luo, J.; Kou, J.; Zheng, H.; Li, B.; Zhang, Z. A molecularly imprinted polymer based a lab-on-paper chemiluminescence device for the detection of dichlorvos. Spectrochim. Acta Part A Mol. Biomol. Spectrosc. 2015, 141, 51-57. [CrossRef]

227. Xiao, L.; Zhang, Z.; Wu, C.; Han, L.; Zhang, H. Molecularly imprinted polymer grafted paper-based method for the detection of 17 $\beta$-estradiol. Food Chem. 2017, 221, 82-86. [CrossRef] [PubMed]

228. Fang, M.; Zhou, L.; Zhang, H.; Liu, L.; Gong, Z.-Y. A molecularly imprinted polymers/carbon dots-grafted paper sensor for 3-monochloropropane-1,2-diol determination. Food Chem. 2019, 274, 156-161. [CrossRef] [PubMed]

229. Caro, N.; Bruna, T.; Guerreiro, A.; Alvarez-Tejos, P.; Garretón, V.; Piletsky, S.; González-Casanova, J.; Rojas-Gómez, D.; Ehrenfeld, N. Florfenicol Binding to Molecularly Imprinted Polymer Nanoparticles in Model and Real Samples. Nanomaterials 2020, 10, 306. [CrossRef] [PubMed]

230. Lowdon, J.W.; Diliën, H.; Singla, P.; Peeters, M.; Cleij, T.J.; van Grinsven, B.; Eersels, K. MIPs for commercial application in low-cost sensors and assays-An overview of the current status quo. Sens. Actuators B Chem. 2020, 325, 128973. [CrossRef]

231. Canfarotta, F.; Poma, A.; Guerreiro, A.; Piletsky, A.G.S. Solid-phase synthesis of molecularly imprinted nanoparticles. Nat. Protoc. 2016, 11, 443-455. [CrossRef] [PubMed]

232. Capoferri, D.; Álvarez-Diduk, R.; Del Carlo, M.; Compagnonea, D.; Merkoçi, A. Electrochromic Molecular Imprinting Sensor for Visual and Smartphone-Based Detections. Anal. Chem. 2018, 90, 5850-5856. [CrossRef] [PubMed]

233. Sergeyeva, T.; Yarynka, D.; Dubey, L.; Dubey, I.; Piletska, E.; Linnik, R.; Antonyuk, M.; Ternovska, T.; Brovko, O.; Piletsky, S.; et al. Sensor Based on Molecularly Imprinted Polymer Membranes and Smartphone for Detection of Fusarium Contamination in Cereals. Sensors 2020, 20, 4304. [CrossRef] [PubMed] 